\title{
Depolanmış Tarama Çamurlarının Sıkışabilirlik ve Mukavemet Davranışının Laboratuvar ve Arazi Deneyleri ile İncelenmesi
}

\author{
Perihan BİÇER ${ }^{1}$ \\ Havvanur KILIÇ ${ }^{2}$ \\ Pelin ÖZENER ${ }^{3}$
}

ÖZ

Bu çalışmada, Haliç tarama çamurunun karada depolanması durumunda, kendi ağırlığı altında ve sürşarj yükleri etkisindeki sıkışabilirlik ve mukavemet davranışı incelenmiştir. Bu amaçla, taranan çamurun karada depolanması durumunda kendi ağırlığı altında konsolidasyon davranışını incelemek için laboratuvarda dört adet büyük boyutlu model deney ve bir adet küçük boyutlu sedimantasyon deneyi gerçekleştirilmiştir. Bu deneylerde kendi ağırlığı altında konsolidasyondan sonra alınan örselenmemiş numuneler üzerinde yapılan ödometre deneyleri ile sürşarj yükleri etkisindeki sıkışabilirlik ve model deneylerde yapılan veyn deneyi ile derinlik boyunca drenajsız kayma mukavemeti ölçülmüştür. Zeminin kendi ağırlığı altındaki konsolidasyon davranışını incelemek için gerçekleştirilen model deneyler ve sedimentasyon deneyinden ölçülen oturma değerlerinden konsolidasyon katsayısı $\mathrm{c}_{\mathrm{v}}$ 'nin 0.91-10.72 $\mathrm{m}^{2} / \mathrm{y} 1 \mathrm{l}$ aralığında ve drenajsız kayma mukavemetinin de 4-20 kPa arasında değiştiği belirlenmiştir. Tarama çamurunun karada depolanmasından 13 yıl sonra yapılan arazi deneylerinden belirlenen drenajsız kayma mukavemeti (SPT N darbe sayısına bağlı olarak ve UU deneylerinden) benzer şekilde $c_{\mathrm{u}}=4-20 \mathrm{kPa}$ arasında değişim göstermiştir. Haliç'ten taranan ve eski taş ocağında depolanan yaklaşık $25 \mathrm{~m}$ kalınlıktaki tarama çamurunun düşük taşıma gücüne ve yüksek sıkışabilirliğe sahip olduğu tespit edilmiştir.

Anahtar Kelimeler: Kendi ağırlığı altında konsolidasyon, sürşarj yükleri, tarama çamuru, kayma mukavemeti, sıkışabilirlik.

\footnotetext{
Not: Bu yazı

- Yayın Kurulu’na 27 Kasım 2019 günü ulaşmıştır. 2 Mart 2020 günü yayımlanmak üzere kabul edilmiştir.

- 31 Mart 2021 gününe kadar tartışmaya açıktır.

- https://doi.org/10.18400/tekderg.651458

1 Namık Kemal Üniversitesi, Çorlu Mühendislik Fakültesi, İnşaat Mühendisliği Bölümü, Tekirdağ pbicer@nku.edu.tr - https://orcid.org/0000-0002-4966-4719

2 Yıldız Teknik Üniversitesi, İnşaat Mühendisliği Bölümü, İstanbul - kilic@yildiz.edu.tr https://orcid.org/0000-0001-9455-1687

3 Yıldız Teknik Üniversitesi, İnşaat Mühendisliği Bölümü, İstanbul - tohumcu@yildiz.edu.tr https://orcid.org/0000-0002-9407-286X
} 


\section{ABSTRACT \\ Investigation of Compresibility and Strength Behaviour of Deposited Dredged Slurries by Laboratory and Field Tests}

In this study, the consolidation and the strength behavior of Haliç dredged slurry stored at a disposal site were investigated through laboratory and field tests. For this purpose, four large scale model tests and a sedimentation test were carried out in the laboratory in order to simulate the consolidation process of the dredged material under self weight conditions. In these tests in order to investigate the compressibility behaviour, consolidation tests were carried out on the undisturbed samples recovered from the sedimentation tests. Additionally, vane test were performed in the large scale model tests to determine the undrained shear strength variation with depth. The coefficient of consolidation $\left(\mathrm{c}_{\mathrm{v}}\right)$ values obtained from the settlements measured in model tests and undrained shear strength values measured from vane tests were determined to be $0.91-10.72 \mathrm{~m}^{2} /$ year and $4-20 \mathrm{kPa}$, respectively. The undrained shear strength values determined from the field tests carried out at the site 13 years after the storage of dredged slurry were determined to be 4-20 kPa based on SPT-N tests and UU tests. As a result of the field tests performed at the disposal site, it is determined that $25 \mathrm{~m}$ thick dredged material deposited at the site has low bearing capacity and high compressibility characterisctics.

Keywords: Self weight consolidation, surcharge loads, dredged sludge, shear strength, compressibility.

\section{GİRIŞ}

Endüstriyel faaliyetler sonucu kirlenen deniz tabanı ve nehir yatakları gibi su yollarının sürdürülebilirliğinin sağlanması için kirliliğe neden olan dip çamurlarının taranarak uygun bir iyileştirme yöntemi ile veya depolama alanında rehabilite edilerek çevreye zarar vermeden kullanılabilirliği sağlanabilir. Genellikle büyük hacimli dipsel çamurun temizlenmesi için kullanılan en ekonomik ve yaygın yöntem taranarak uzaklaştırılmasıdır. Taranan sulu çamurun özelliklerini iyileştirmek ve yıllarca sürebilecek çökelme ve oturma süresini tahmin ederek depolama bölgesinin yeniden kullanıma kazandırılmasını sağlamak amacıyla tarama çamurlarının kendi ağırlığ 1 ve dış yükler altındaki davranışının araştırılması gerekmektedir.

Taranarak depolanmış sulu çamurların çökelmesi, ince danelerin sedimetasyonu ve tortu tabakalarının kendi ağırlığı altında konsolidasyonu şeklinde iki fazda meydana gelmektedir. Birkaç gün ya da birkaç hafta içerisinde sedimentasyon tamamlandıktan sonra efektif gerilmenin oluşmaya başlaması ile kendi ağırlığında konsolidasyon aşamasına geçilir $[1,2]$. Yüksek su muhtevasına sahip yumuşak killerin sedimantasyonu, kendi ağırlığı altında konsolidasyonu ve etkileyen faktörleri incelemek için birçok teorik ve deneysel araştırmalar yapılmıştır $[3,4,5,6,7,8,9,10,11,12,13,14,15,16,17,18,19,20]$. Yüksek su muhtevasına sahip bu zeminlerin konsolidasyon davranışının incelenmesinde çok küçük gerilme seviyelerindeki boşluk oranı-efektif gerilme ve boşluk oranı-permeabilite değişimlerinin dikkate alınması gereklidir [21, 22, 23, 24, 25]. 
Haliç kenarında kurulan sanayi tesisleri nedeniyle had safhaya ulaşan çevresel kirliliğe çözüm bularak Haliç'i su ulaşımı ve rekreasyon gibi faydalı amaçlar için tekrar kullanılabilir hale getirmek için çalışmalar yapılmıştır. Haliç Islah Projesi kapsamında yapılan araştırmalar sonucu taranan dip çamurun Alibeyköy'de kullanılmayan eski taş ocaklarında depolanmasına karar verilmiştir [26]. Bu kapsamda yaklaşık 5 milyon metreküp dipsel çamur 1997-1998 yılları arasında Şekil 1'de gösterilen sahada depolanmıştır. Bu çamurunun kendi ağırlığı altında konsolidasyon davranışı laboratuvarda deneysel olarak ve sayısal analizler ile incelenmiştir. Laboratuvarda sızıntı etkili konsolidasyon deneyleri ile düşük gerilme seviyelerini de içerecek şekilde efektif gerilme-boşluk oranı $\left(\mathrm{e}-\sigma \mathrm{v}^{\prime}\right)$ ve permeabilite-boşluk oranı (k-e) ilişkileri araştırılmıştır [27]. Ayrıca bu deneysel ölçümlerden elde edilen oturmazaman davranışı, non-lineer sonlu şekil değiştirmeli konsolidasyon analizleri ile modellenmiştir $[27,28]$.

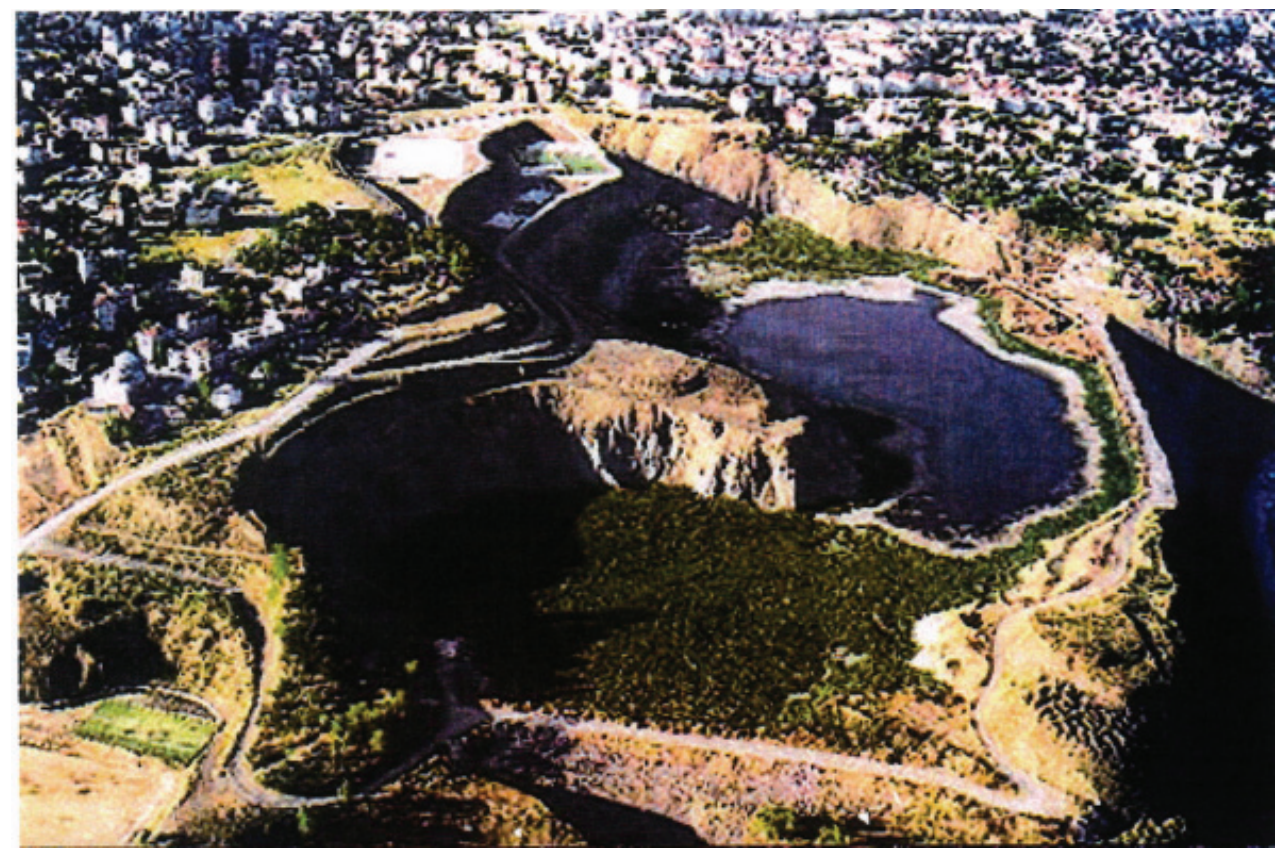

Şekil 1 - Alibeyköy'de taş ocaklarl görünümü [29]

Haliç'den taranan çamurun Şekil 1'de gösterilen sahada depolanmasından yaklaşık 13 yıl sonra, depolama alanı ve çevresini de içine alacak şekilde inşası planlanan yapıların tasarımı için sondaj çalışmaları gerçekleştirilmiştir. Bu kapsamda arazide sondajlar sırasında standart penetrasyon deneyleri yapılmış ve örselenmiş ve örselenmemiş zemin örnekleri alınmıştır. $\mathrm{Bu}$ zemin örnekleri üzerinde endeks özellikler, sınıflandırma, sıkışabilirlik ve mukavemet deneyleri gerçekleştirilmiştir [29]. Yapılan bu çalışmaların değerlendirilmesi sonucu depolanan tarama çamurunun kendi ağırlığ tespit edilmiştir. Böylece, yapılan çalışmalar ile İstanbul/Alibeyköy'de yer alan ve atıl halde bulunan bir taş ocağı sahası rekreasyon alanına dönüşmüştür. 
$\mathrm{Bu}$ makalede, taranarak depolanan yüksek su muhtevasına sahip zeminlerin kendi ağırlığı altında konsolidasyon ve sürşarj yükleri altındaki sıkışabilirlik ve mukavemet parametrelerinin laboratuvar ve arazide yapılan çalışmalar ile incelenmesi sunulmuştur. $\mathrm{Bu}$ amaca yönelik olarak önce laboratuvarda dört adet büyük boyutlu model deney ve bir adet küçük boyutlu sedimantasyon deneyi ile kendi ağırlığı altında konsolidasyon davranışı incelenmiştir. Zeminin kendi ağırlığı altında konsolidasyonu tamamlandıktan sonra alınan iki adet örselenmemiş numune üzerinde sürşarj yükleri etkisindeki sıkışabilirlik davranış1 standart ödometre deneyi ile araştırılmıştır. Model deneylerde, kendi ağırlığı altında konsolidasyon tamamlandıktan sonra plaka yükleme deneyi yapılarak taşıma gücü tahmin edilmiş ve derinlik boyunca drenajsız kayma mukavemeti el veyni ile ölçülmüştür [33]. Depolama sahasında 2011 yılında yapılan sondajlar sırasında SPT deneyleri yapılmış ve alınan örselenmemiş örnekler üzerinde laboratuvarda ödometre ve konsolidasyonsuzdrenajsız (UU) üç eksenli basınç deneyleri yapılarak, drenajsız kayma mukavemeti ve sıkışabilirlik parametreleri belirlenmiştir. Böylece depolama sahasındaki zeminin depolama sonrası ve kendi ağırlığı altındaki konsolidasyondan sonraki davranışı değerlendirilmiştir.

\section{TARAMA ÇAMURUNUN ÖZELLIKLERİ}

Deneysel çalışmalarda kullanılan numuneler, Haliç'ten taranarak Alibeyköy'deki eski taş ocaklarına taşınarak depolanan zeminden alınmıştır. Bu zemin üzerinde sınıflandırma (elek analizi, hidrometre, özgül ağırlık) [30] ve Atterberg limitleri [31], organik madde tayin [32] deneyleri yapılmıştır. Deney sonuçları Çizelge 1'de özetlenmiştir [33]. Zemin sınıfı, birleştirilmiş zemin sınıflandırma sistemi (USCS)'ne göre yüksek plastisiteli silt (MH) veya organik silt $(\mathrm{OH})$ olarak belirlenmiştir.

\section{Çizelge 1 - Haliç Tarama Çamuru'nun İndeks Özellikleri [33]}

\begin{tabular}{|l|c|}
\hline Özellik & Değer \\
\hline Su Muhtevası (\%) & 95 \\
\hline Plastik Limit (\%) & 50 \\
\hline Likit Limit (\%) & 75 \\
\hline Plastisite İndisi (\%) & 25 \\
\hline Organik Madde İçeriği (\%) & 12.60 \\
\hline Danelerin Özgül Ağırlığı & 2.72 \\
\hline
\end{tabular}

Tarama çamurunun depolama alanına boşaltılması sırasındaki su muhtevasının \%300 olduğu bilinmekte, ancak depolama sahasından laboratuvara getirtilen zemin numunesinin su muhtevası \%95 olarak belirlenmiştir. Depolama alanındaki başlangıç koşullarını örneklemek amacıyla, model deneyler için hazırlanan bulamaç çamurun su muhtevası \% 095 'ten \%300'e çıkarılacak şekilde $\% 0.8$ tuzlu su eklenerek $1.17 \mathrm{gr} / \mathrm{cm}^{3}$ yoğunluğunda bir süspansiyon elde edilmiştir. Hazırlanan bulamaç çamurun, yaklaşık olarak 2-3 hafta hava ile teması kesilerek bekletilmiş ve zaman zaman mikserle karıştırılarak homojen ve suya doygun hale gelmesi 
sağlanmıştır. Bütün model deneylerde benzer koşullarda hazırlanmış bulamaç çamur numuneleri kullanılmıştır.

\subsection{Kendi Ağırlığı Altında Konsolidasyon}

Depolama alanında su muhtevası yüksek Haliç Tarama Çamuru'nun, kendi ağırlığı altında konsolidasyonu ve zamana bağlı değişimini tahmin etmek amacıyla, laboratuvarda dört adet model deney ve bir adet küçük boyutlu deney gerçekleştirilmiştir. Çizelge 2'de bu deneylere ait özellikler sunulmuştur. Model Deneyl'de zeminin kendi ağırlığ 1 altında konsolidasyonu tamamlandıktan sonra vakumlu bir tüp ile örselenmemiş numune alınarak standart ödometre deneyi yapılmıştır. Küçük boyutlu sedimentasyon deneyinde de zeminin kendi ağırlığı altında konsolidasyonu tamamlanıp (1.41 kPa, 3.82 kPa, $7.29 \mathrm{kPa}, 13.66 \mathrm{kPa}$ ve $26.39 \mathrm{kPa})$ kademeli yükler etkisi altında bırakıldıktan sonra örselenmemiş numune alınarak sürşarj gerilmeleri altındaki sıkışabilirlik davranışı standart ödometre deneyi ile araştırılmıştır.

Çizelge 2 - Laboratuvarda yapılan deneylere ait özellikler

\begin{tabular}{|c|c|c|c|c|c|}
\hline & $\begin{array}{c}\text { Model } \\
\text { Deney } 1\end{array}$ & $\begin{array}{c}\text { Model } \\
\text { Deney } 2\end{array}$ & $\begin{array}{c}\text { Model } \\
\text { Deney } 3\end{array}$ & $\begin{array}{c}\text { Model } \\
\text { Deney } 4\end{array}$ & $\begin{array}{c}\text { Küçük } \\
\text { Boyutlu } \\
\text { Deney }\end{array}$ \\
\hline $\begin{array}{c}\text { Wbaşlangıç } \\
(\%)\end{array}$ & 300 & 300 & 300 & 300 & 390 \\
\hline $\begin{array}{l}\mathrm{W}_{\mathrm{son}} \\
(\%)\end{array}$ & 77.5 & 100 & 87 & 92 & 107 \\
\hline $\begin{array}{l}\text { Başlangıç sulu çamur } \\
\text { yüksekliği (mm) }\end{array}$ & 950 & 980 & 950 & 960 & 748 \\
\hline $\begin{array}{l}\text { Kendi ağırlığı altında } \\
\text { konsolidasyon süresi } \\
\text { (gün) }\end{array}$ & 457 & 60 & 52 & 109 & 126 \\
\hline Tüp numune alımı & + & - & - & - & - \\
\hline Plaka yükleme deneyi & + & + & + & + & - \\
\hline El veyn deneyi & + & + & + & + & - \\
\hline Ödometre deneyi & + & - & - & - & + \\
\hline Şürşarj gerilmesi & yok & yok & yok & yok & var \\
\hline
\end{tabular}

Model Deneylerde Şekil 2'de gösterilen $1.00 \mathrm{~m}$ yüksekliğinde ve $0.80 \mathrm{~m}$ çapında silindirik tank kullanılmıştır [33]. Hazırlanan sulu çamur, tanka bir pompa yardımı ile yerleştirilmiş ve yaklaşık olarak toplam ağırlığı 460-500 kg aralığında değişmiştir. Silindirin yanlarında değişik derinliklerde 6 adet ve altında da 1 adet olmak üzere 7 adet drenaj vanası mevcuttur. Vanaların ağızlarına geotekstil yerleştirilerek zeminin bu vanalardan dışarı çıkışı 
engellenmiştir. Bulamaç çamur, tanka yerleştirildikten sonra kendi ağırlığı altında meydana gelen oturmaların zamana bağlı değişimi ölçülmüştür.

Deneylerde tankın altından su çıkışına izin verilerek çift yönlü drenaj altında konsolidasyonunun gerçekleşmesi sağlanmış ve taban drenajını sağlamak için tankın tabanına $20 \mathrm{~mm}$ kalınlığında çakıl yerleştirilerek üzerine geotekstil şilte serilmiştir. Sedimantasyon sonucu yüzeyde oluşan saydam süpernatan su tabakası üstten kaldırılmıştır. Model deneylerde sırasıyla, kendi ağırlığ 1 altında alınan oturma ölçümleri 457, 60, 52 ve 109 gün devam etmiştir. Elde olunan oturma-zaman eğrileri Şekil 3'de sunulmuştur. Görüldüğü gibi Deney2, Deney3 ve Deney4'te alınan oturma-zaman ölçümleri birbirine benzerdir. Model Deney1'de, tankın yanlarında yer alan vanalardan su çıkışına izin verilmiş ve 457 gün okumalara devam edilmiştir. Bu nedenlerle oturma-zaman grafiği diğerlerinden farklıdır. Deneylerde yaklaşı olarak $0.43 \mathrm{~m}-0.55 \mathrm{~m}$ arasında oturma meydana gelmiştir. Oturma zaman ölçümleri ayrıca büyük şekil değiştirme konsolidasyon teorisini de dikkate alan CS2 [34] programı ile analiz edilmiş ve sonuçlar Berilgen vd. [27] tarafından sunulmuştur.

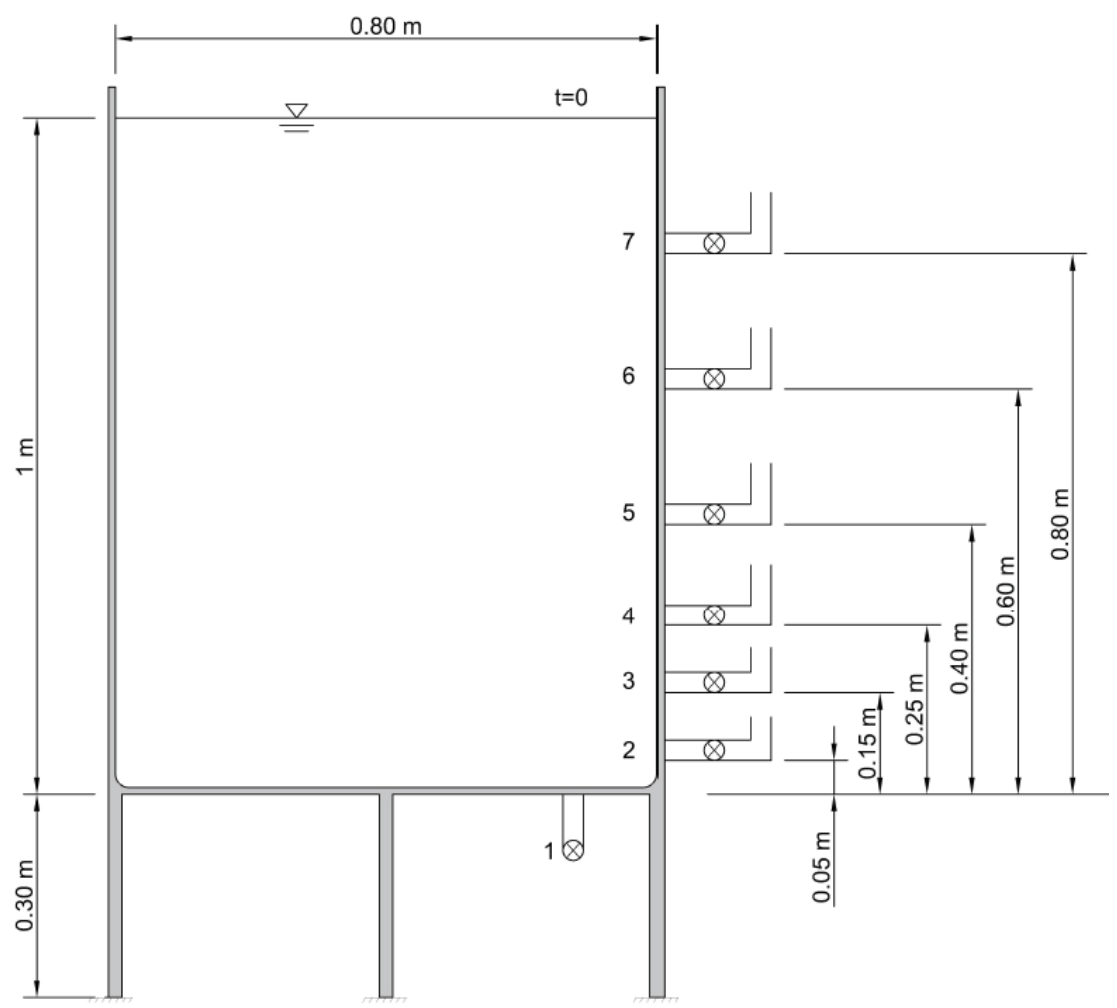

Şekil 2 - Laboratuvarda Model Deneylerde Kullanılan Tank [33] 

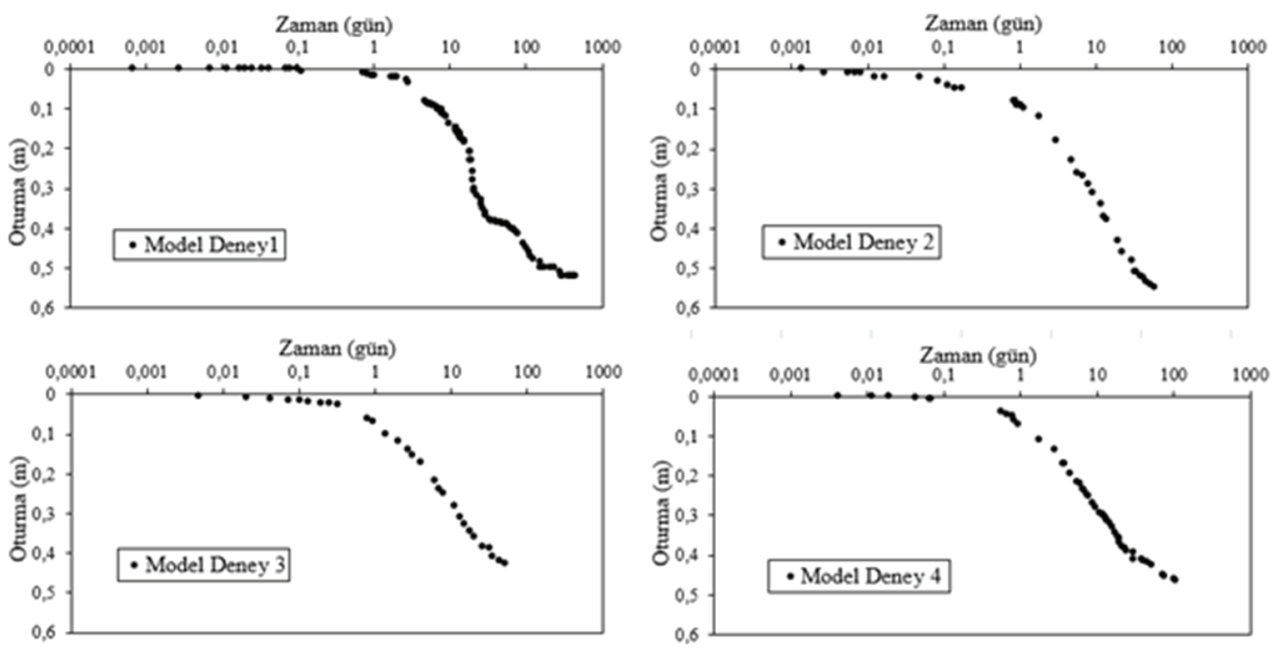

Şekil 3 - Büyük boyutlu model deneyler ile ölçülen oturma - zaman ilişkileri (a) Model Deney1, (b) Model Deney2, (c) Model Deney3, (d) Model Deney 4

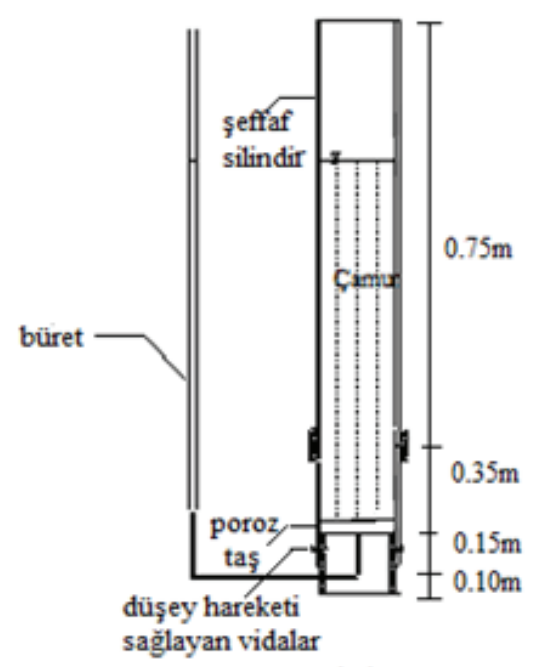

(a)

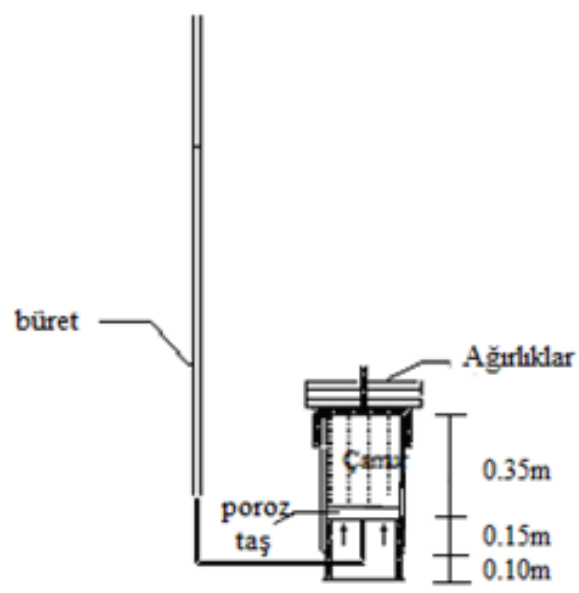

(b)

Şekil 4 - Küçük boyutlu deney düzeneğinde (a) kendi ă̆ırlı̆̆ı altında konsolidasyon (sedimentasyon deneyi) (b) sürşarj etkisinde konsolidasyon [35]

Sulu çamur zeminin, laboratuvarda kendi ağırlığı altında konsolidasyon davranışını incelemek için Şekil 4'te gösterilen küçük boyutlu deney düzeneğinden de yararlanılmıştır. Bu düzenek daha önce Haliç Tarama Çamurunun sedimantasyon davranışını incelemek üzere 
yapılan çalışmada kullanılmıştır [35]. \%390 su muhtevasına sahip bulamaç çamur iki parçadan oluşan şeffaf silindirler içinde kendi ağırlığı altında konsolide edilmiştir (Şekil 4a). Sedimentasyon deneyi bitiminde numunenin su muhtevası \%107 olarak saptanmıştır. Daha sonra deney aletinin üst parçası çıkarılmış ve alt kısımda kalan numunenin çok yumuşak olması nedeniyle önce aynı deney aletinde kademeli olarak $26.39 \mathrm{kPa}$ 'a ulaşana kadar konsolide edilmişstir. Bu konsolidasyonda yükleme kademeleri sırasıyla $1.41 \mathrm{kPa}, 3.82 \mathrm{kPa}$, $7.29 \mathrm{kPa}, 13.66 \mathrm{kPa}$ ve $26.39 \mathrm{kPa}$ olarak uygulanmıştır (Şekil 4b). $26.39 \mathrm{kPa}$ yük kademesi sonunda toplam sıkışma miktarı $0.0485 \mathrm{~m}$ 'dir. Bu aşamadan sonra $26.39 \mathrm{kPa}$ 'a kadar konsolide edilmiş sedimentasyon numunesinden klasik ödometre deneyi için numune alınmış ve bu numune "sedimentasyon numunesi" olarak ifade edilmiştir. Şekil 5 'te bu deney düzeneğinde, başlangıç su muhtevası \%390 olan numunenin kendi ağırlığı altında elde edilen oturma - zaman eğrisi gösterilmiştir. Bu deneyde de yaklaşık olarak $0.5 \mathrm{~m}$ 'lik oturma meydana gelmiştir.

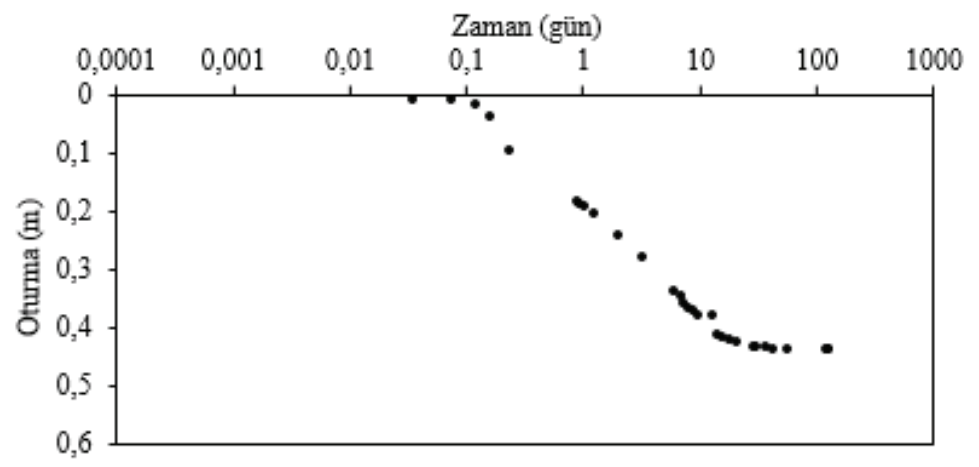

Şekil 5 - Küçük boyutlu deney düzeneğinde ölçülen oturma - zaman ilişkisi

\subsection{Drenajsız Kayma Mukavemetinin Belirlenmesi}

Drenajsız kayma mukavemeti, doygun killerde temel taşıma kapasitesi ve dolgu stabilitesinin değerlendirilmesi için gerekli bir parametredir ve laboratuvar ve arazi deneylerinden belirlenebilmektedir. Bu çalışma kapsamında yapılan model deneylerde, el veyn deney aleti kullanılarak kendi ağırlığı altında konsolidasyonu tamamlanan zeminde drenajsız kayma mukavemeti ölçülmüştür. Şekil 6a'da el veyn deney aleti ve tank üzerinde monte edilen ask1 sistemi gösterilmiştir. Veyn ile yapılan kayma mukavemeti ölçümlerinde $0-28 \mathrm{kPa}$ aralığındaki kayma mukavemeti için önerilen $33 \mathrm{~mm}$ çapındaki veyn kanatlı kesici uç kullanılmıştır. Model deneylerde veyn deneyi yapılan noktaların konumları, konsolidasyon numunesi yeri ve plaka yükleme deneyi konumu Şekil 6b'de gösterilmiştir.

Model Deney1'de kendi ağırlığı altında konsolidasyon sonrasında, özel yaptırılmış vakumlu tüp numune alıcı zemine batırılmış ve bu sırada veyn aleti askı sistemine yerleştirildikten sonra derinlik boyunca ölçümler yapılmıştır. Veyn aleti ile ölçümler bittikten sonra vakumlu numune alıcı ile örselenmemiş numune alım işlemi gerçekleştirilmiştir. Sonrasında plaka yükleme deneyi uygulanmıştır. 


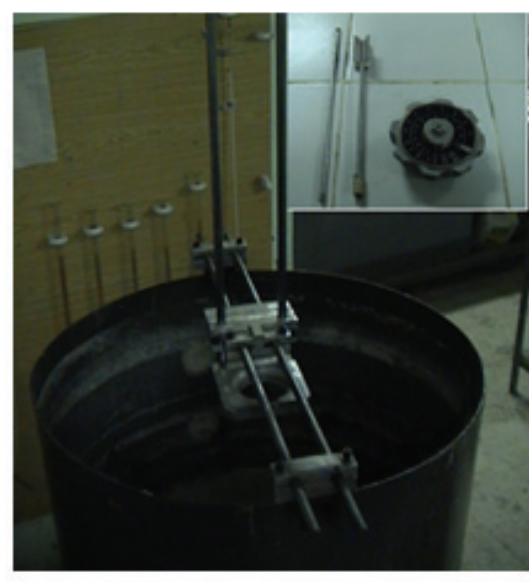

(a)

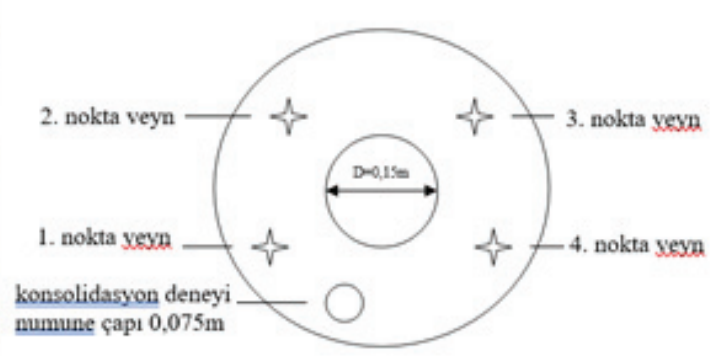

(b)

Şekil 6 - (a) Model deney tankı üzerine yerleştirilen veyn ask sistemi, el veyn deney aleti (b) Veyn ve plaka yükleme deney noktaları ve konsolidasyon numunesi konumları [33].

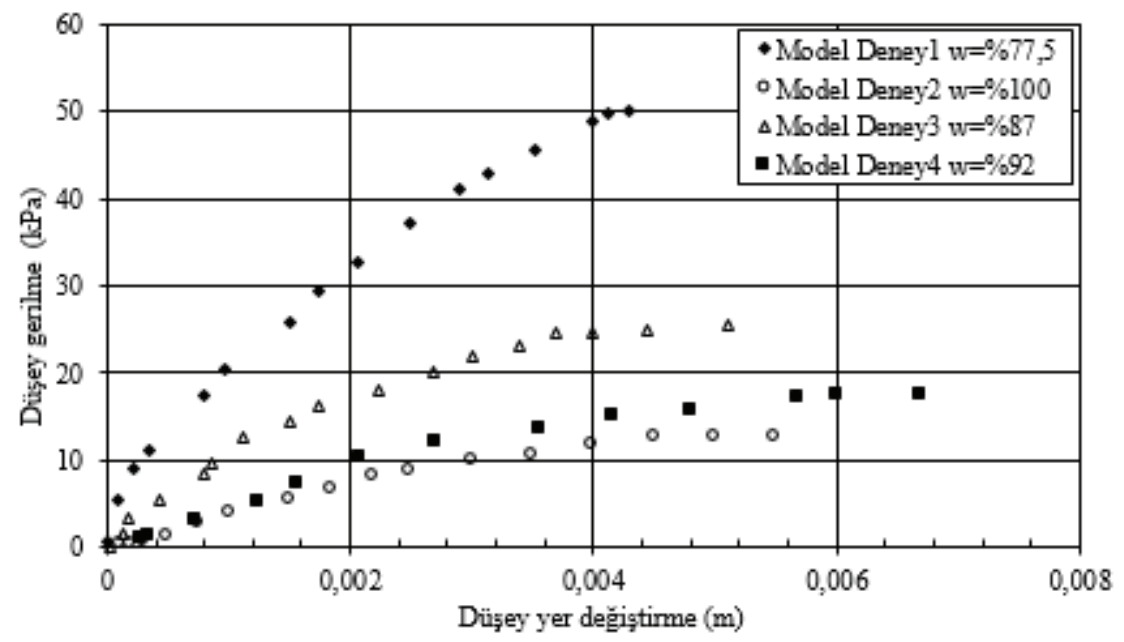

Şekil 7 - Model deneylerde yapılan plaka yükleme deneyi sonuçları

\subsection{Plaka Yükleme Deneyleri}

Model deneylerde Şekil 2'de gösterilen tank içine yerleştirilen sulu çamur kendi ağırlığı altında konsolide olduktan sonra plaka yükleme deneyi yapılmıştır. Şekil 6b'de gösterildiği gibi zemin yüzünde, tank merkezine yerleştirilen $0.15 \mathrm{~m}$ çapında ve $0.025 \mathrm{~m}$ kalınlığında çelik plaka düşeyde $0.0014 \mathrm{~mm} / \mathrm{sn}$ 'lik yükleme hızı ile yüklenmiştir. Plaka yükleme deneylerinden elde edilen gerilme-düşey yer değiştirme eğrileri Şekil 7'de gösterilmiştir. Yüklemeye 
zeminin taşıma gücü aşılana kadar veya limit değer olarak kabul edilen plaka oturması değeri elde edilinceye kadar devam edilmiştir. Görüldüğü gibi oturmaları en uzun süre izlenen Model Deney 1'de en yüksek gerilme değeri ölçülmüştür. Küçükten büyüğe sırası ile su muhtevası ile uyumlu düşey gerilme değerleri belirlenmiştir.

\subsection{Depolama Sahasında Yapılan Sondajlar ve Arazi Deneyleri}

Haliç'ten taranan dip çamurunun depolama işleminin büyük bölümü bir yıl içinde (Nisan 1997 - Nisan 1998) tamamlanmıştır. Depolanan yüksek su muhtevasına sahip tarama malzemesi kendi ağırlığı altında konsolidasyonunu tamamlandıktan sonra, depolama alanı ve çevresinde Tema park projesi planlanmıştır. Bu kapsamda, depolama alanının jeolojisini ortaya koymak amacıyla 2011 yılında derinlikleri 15-30 m arasında değişen zemin araştırma sondajları yapılmıştır. Şekil 8'de sahada gerçekleştirilen sondajlardan belirlenen iki jeolojik kesit gösterilmiştir. Bu kesitlerden görüldüğü gibi, sahada kalınlığ $7.30 \mathrm{~m}$ ile $25 \mathrm{~m}$ arasında değişen tarama çamuru ve hemen altında Trakya Formasyonu'na ait grovak birimler yer almaktadır. Depolama sahasında yapılan sondajlarda, çeşitli derinliklerde standart penetrasyon deneyleri uygulanmış, örselenmiş ve örselenmemiş numuneler alınmıştır. Sahadan alınan numuneler üzerinde yapılan sınıflandırma deneylerinde, düşük plastisiteli kil (CL), yüksek plastisiteli kil (CH), düşük plastisiteli silt (ML) ve yüksek plastisiteli silt (MH) zeminler ile karşılaşılmıştır. Alınan zemin örneklerinin su içeriği $\left(\mathrm{w}_{\mathrm{n}}\right) \%$ 6.41- \%59.92, plastik limit değerleri ( $\mathrm{W}_{\mathrm{P}}$ ) \%18-41 ve likit limit değerleri $\left(\mathrm{W}_{\mathrm{L}}\right)$ \% 16-33 aralıklarında değişim göstermiştir. SPT-N değerlerinin ve Atterberg limitlerinin derinlikle değişimi Şekil 9'da sunulmuştur.

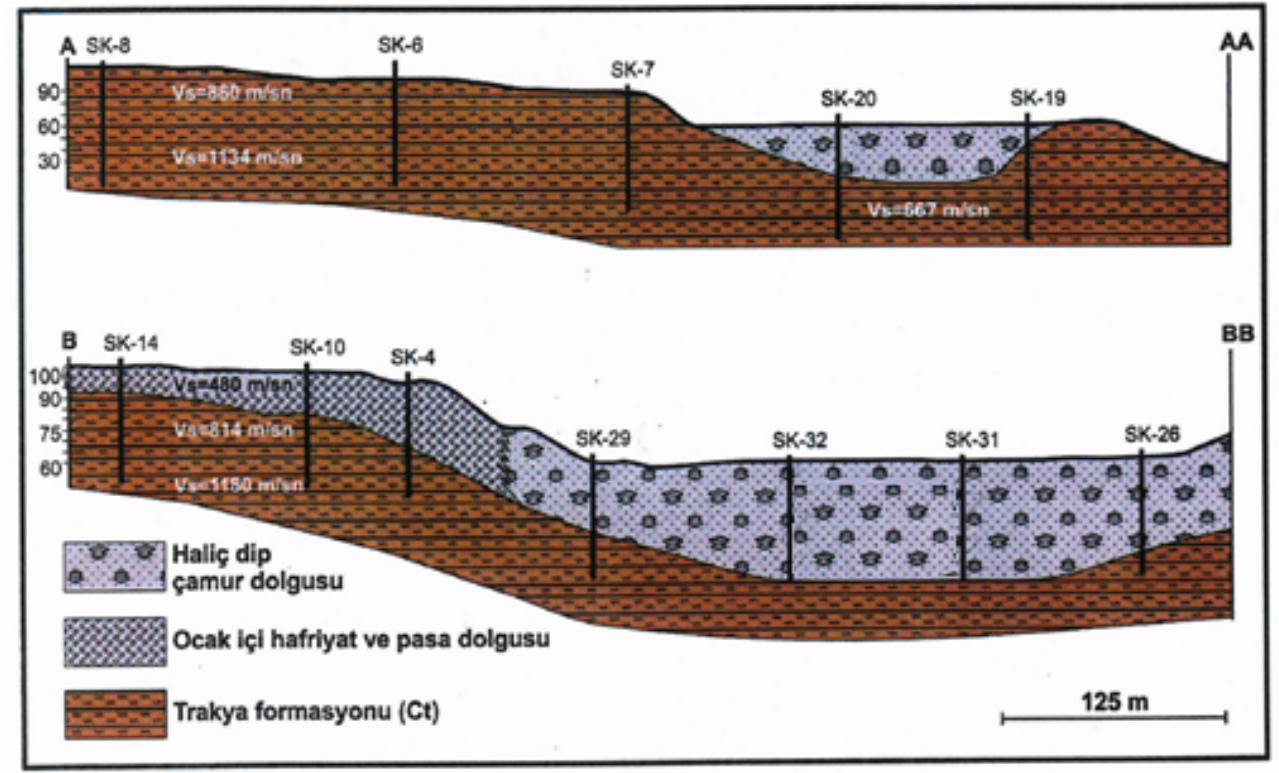

Şekil 8 - Tarama çamurunun depolandı̆̆ sahaya ait jeolojik kesitler [29] 

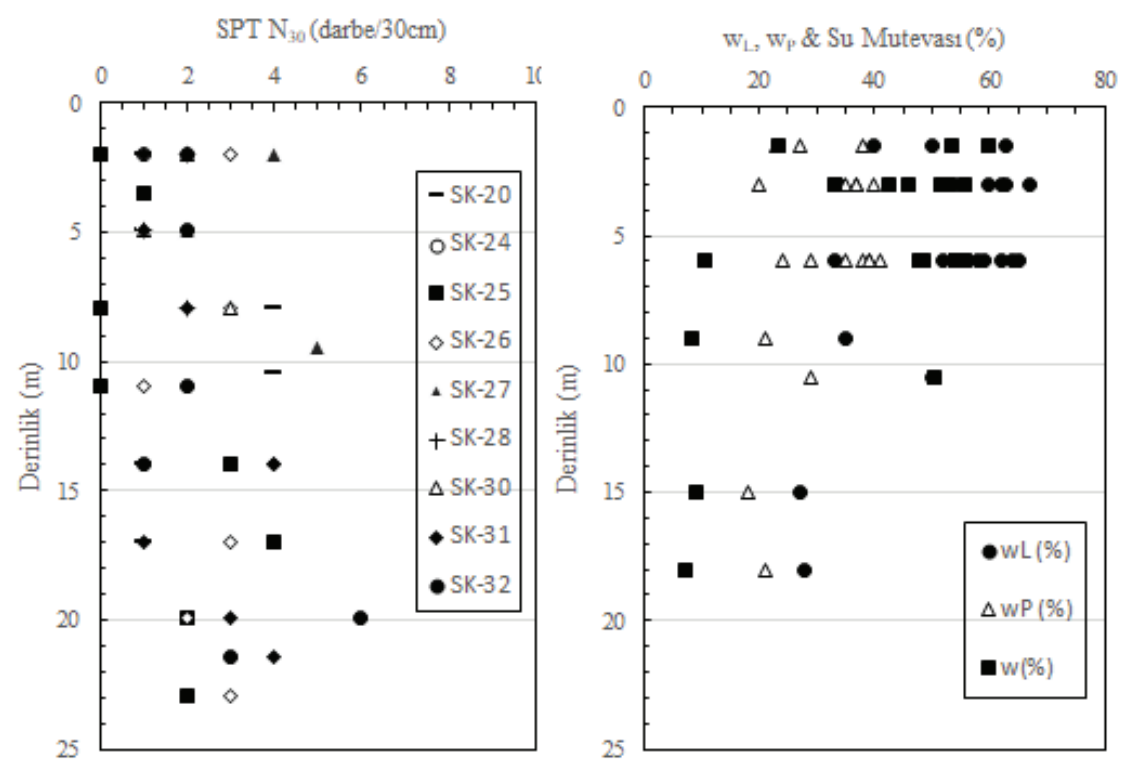

Şekil 9 - Depolama sahasinda yapılan sondajlardan (a) SPT $N_{30}$ (b) $w_{L}, w_{P}$ ve $w_{n}$ değerlerinin derinlik ile değisşimi

\section{MODEL DENEYLER VE DEPOLAMA SAHASINDA YAPILAN ÇALIŞMALARIN DEĞERLENDIRILMESI}

\subsection{Model Deneylerden Konsolidasyon Katsayısının Belirlenmesi}

Konsolidasyon katsayısı $\left(\mathrm{c}_{\mathrm{v}}\right.$ ) zeminin konsolidasyon süresini kontrol eden tek parametredir. Konsolidasyon deneylerinden konsolidasyon katsayısının belirlenmesi için birçok yöntem mevcuttur, bu yöntemlerden biri de Asoaka [36] yöntemidir. Bu yöntemde seçilen sabit bir zaman aralığında düşey eksende oturma $\left(S_{n}\right)$ ile yatay eksende bir önceki oturma $\left(S_{n-1}\right)$ değerlerinin değişimi çizilir. Oturma noktalarından en uygun doğru geçirilerek, $45^{0}$ doğrusu ile kesiştirilir. Kesişim noktasından nihai konsolidasyon oturması $\mathrm{S}_{\mathrm{f}}$ bulunur. Oluşturulan doğrunun eğimi $(\beta)$ kullanılarak, konsolidasyon katsayısı $\left(\mathrm{c}_{\mathrm{v}}\right)$ belirlenir. Eşitlik 1'de çift yönlü drenaj koşulu için $\mathrm{c}_{\mathrm{v}}{ }^{\prime}$ nin hesaplanması gösterilmiştir. Burada, $\Delta \mathrm{t}$ seçilen sabit zaman aralığını ve H sıkışabilir tabaka kalınlığını göstermektedir.

$c_{v}=\left(\frac{H^{2}}{6 \Delta t}\right) \ln \beta \quad$ (çift yönlü drenaj için)

Oturma okumalarının aralığı Model Deneyl'de, $\Delta \mathrm{t}=10$ gün, Model Deney 2 ve Model Deney 3 'te $\Delta \mathrm{t}=2$ gün ve Model Deney 4 'te $\Delta \mathrm{t}=4$ gün olarak kabul edilerek Asaoka [36] yöntemine göre yapılan değerlendirmenin sonuçları Şekil 10 'da sunulmuştur. Dört deneyde de oturma okumalarının $45^{0}$ lik çizgi üzerine düşmesi nihai oturmaya ulaşıldığını göstermektedir. Eşitlik 1 kullanılarak elde edilen konsolidasyon katsayısı $\mathrm{c}_{\mathrm{v}}$ değerleri $0.91 \mathrm{~m}^{2} / \mathrm{y} 1 \mathrm{l}$ ile $10.72 \mathrm{~m}^{2} / \mathrm{y} 1 \mathrm{l}$ arasında değişim göstermiş ve ortalama değerin ise $6.46 \mathrm{~m}^{2} / \mathrm{y}$ ll olduğu saptanmıştır. 
Şekil 4'te gösterilen küçük boyutlu deney düzeneğinde alınan oturma ölçümleri $\Delta t=2$ gün aralıklarla Asoaka yöntemi ile değerlendirildiğinde (Şekil 11) konsolidasyon katsayısı $\mathrm{c}_{\mathrm{v}}$ değeri $8.51 \mathrm{~m}^{2} / \mathrm{y} ı 1$ olarak hesaplanmıştır.
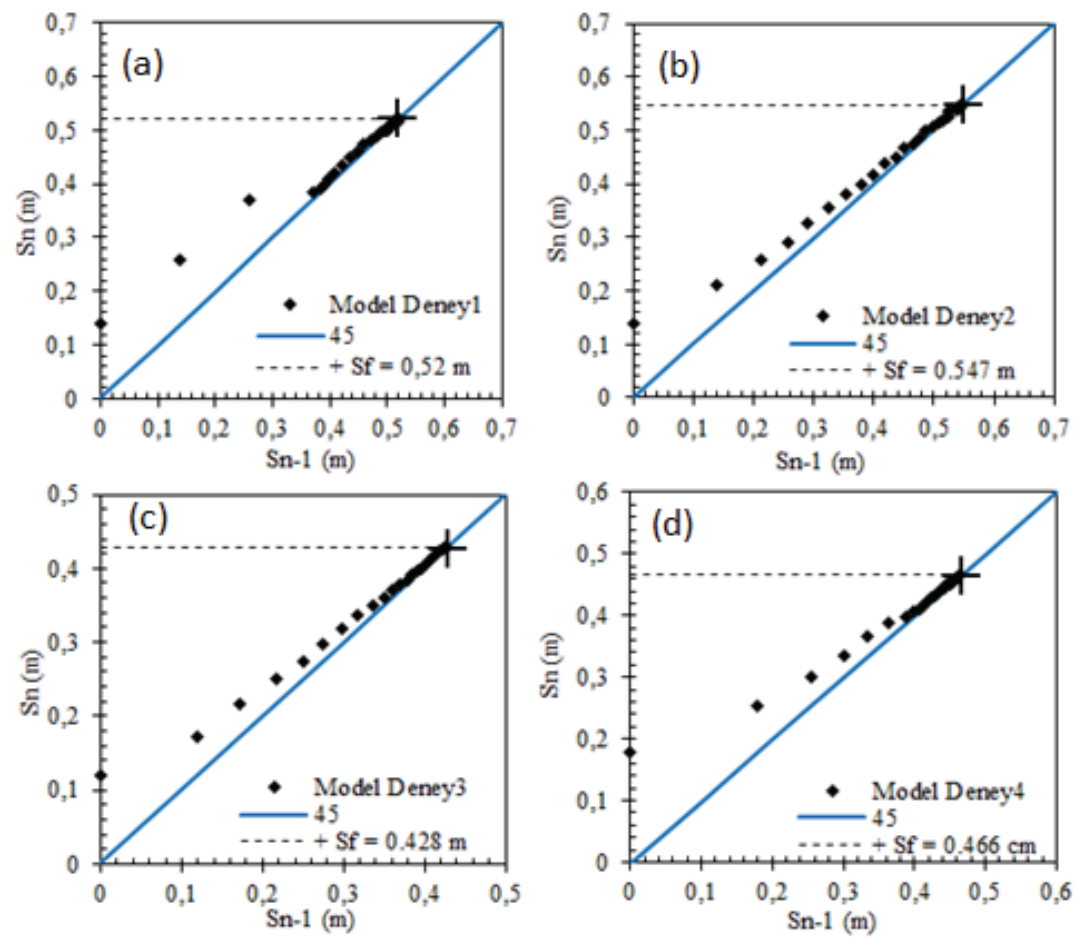

Şekil 10 - Asaoka [36] yöntemi ile Model deneylerde nihai oturmaların tahmini (a)Model Deney 1, (b)Model Deney 2, (c)Model Deney 3, (d)Model Deney 4

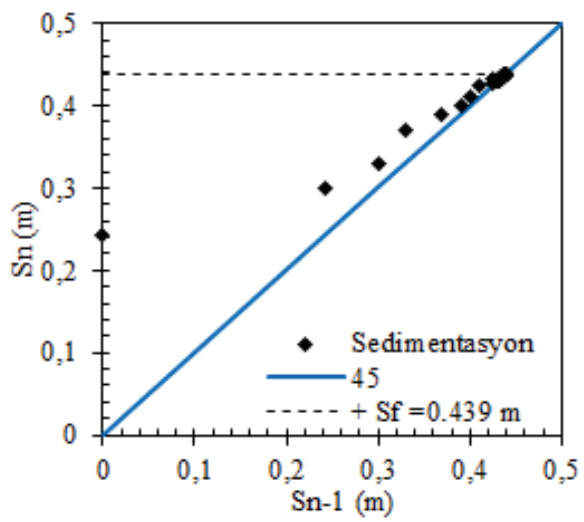

Şekil 11 - Asaoka [36] yöntemi ile küçük boyutlu deney (sedimentasyon deneyi) düzeneğinde nihai oturma 
Model deneylerden ve sedimentasyon deneyinden alınan oturma ölçümlerinin Asaoka [36] ve Casagrande [37] yöntemleri ile değerlendirilmesi sonucu belirlenen konsolidasyon katsayıları $\left(c_{v}\right)$ Çizelge 3'de verilmiştir.

\section{Çizelge 3 - Model deneylerden belirlenen konsolidasyon katsayısı değerleri}

$\begin{array}{ccc}\text { Deney Adı } & \begin{array}{c}\text { Asaoka Yöntemi } \\ \mathrm{c}_{\mathrm{v}}\left(\mathrm{m}^{2} / \mathrm{y} 1 \mathrm{l}\right)\end{array} & \begin{array}{c}\text { Casagrande Yöntemi } \\ \mathrm{c}_{\mathrm{v}}\left(\mathrm{m}^{2} / \mathrm{yl}\right)\end{array} \\ \text { Model Deney 1 } & 0.91 & 1.45 \\ \text { Model Deney 2 } & 10.41 & 2.84 \\ \text { Model Deney 3 } & 10.72 & 3.15 \\ \text { Model Deney 4 } & 3.78 & 4.10 \\ \text { Küçük boyutlu deney } & 8.51 & 14.19 \\ \text { (sedimentasyon deneyi) } & & \end{array}$

\section{2. Ödometre Deneyleri Sonuçları}

Depolanan tarama çamurunun sürşarj yükleri altındaki davranışını incelemek için standart ödometre deneyi yapılarak sıkışabilirlik parametreleri belirlenmiştir. Model Deney 1'den pleksiglas vakumlu numune alıcı ile $75 \mathrm{~mm}$ çapında ve sedimentasyon deneyinde $50 \mathrm{~mm}$ çapında çelik ring ile alınan numuneler üzerinde yapılan standart ödometre deneyinde 24 saat sonundaki boşluk oranı değerlerinin düş̧ey efektif gerilmeye bağlı değişimi Şekil 12'de verilmiştir. Her iki konsolidasyon eğrisinin birbirine çok yakın olduğu görülmektedir. Yalnızca sedimantasyon numunesinin başlangıç boşluk oranı, başlangıç su muhtevası büyük olduğundan daha büyüktür ve sıkışma eğrileri yaklaşık olarak birbirine paraleldir. Çizelge 4 'de farklı gerilme kademelerinde elde edilen konsolidasyon katsayısı değerleri $\left(\mathrm{c}_{\mathrm{v}}\right)$, hacımsal sıkışma katsayısı $\left(\mathrm{m}_{\mathrm{v}}\right)$ ve sıkışma indisi $\left(\mathrm{C}_{\mathrm{c}}\right)$ sunulmuştur.

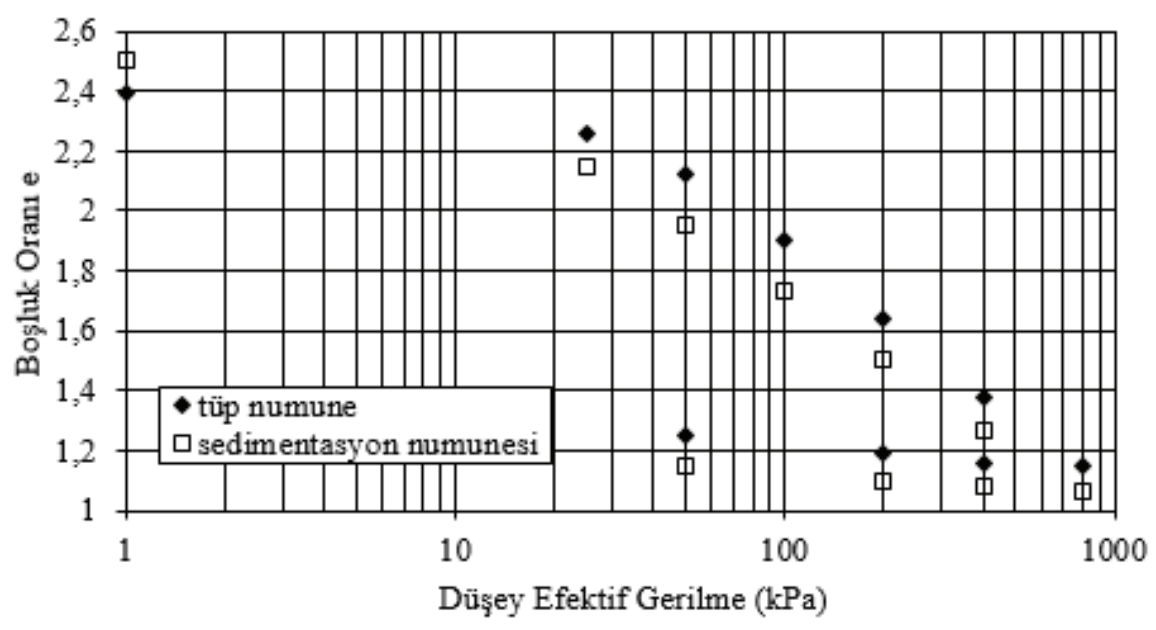

Şekil 12 - Standart ödometre deney eğrileri 
Depolanmış Tarama Çamurlarının Sıkışabilirlik ve Mukavemet Davranışının ...

Çizelge 4 - Standart ödometre deneylerinden belirlenen parametreler

\begin{tabular}{|c|c|c|c|c|c|}
\hline $\begin{array}{c}\text { Numune } \\
\text { Türü }\end{array}$ & $\begin{array}{c}\text { Gerilme } \\
\text { Kademesi } \\
(\mathrm{kPa})\end{array}$ & $\begin{array}{c}\mathrm{c}_{\mathrm{v}} \\
\left(\mathrm{m}^{2} / \mathrm{y} 1 \mathrm{l}\right)\end{array}$ & $\begin{array}{c}\text { Gerilme } \\
\text { Aralığı } \\
(\mathrm{kPa})\end{array}$ & $\begin{array}{c}\mathrm{m}_{\mathrm{v}} \\
(\mathrm{kPa})^{-1}\end{array}$ & $\mathrm{C}_{\mathrm{c}}$ \\
\hline \multirow{6}{*}{$\begin{array}{c}\text { Model Deney } 1 \\
\text { (tüp numune) }\end{array}$} & 25 & 2.47 & $0-25$ & $15.97 \times 10^{-3}$ & \multirow{6}{*}{0.76} \\
\hline & 50 & 1.29 & $25-50$ & $17.17 \times 10^{-3}$ & \\
\hline & 100 & 1.22 & $50-100$ & $14.10 \times 10^{-3}$ & \\
\hline & 200 & 1.11 & $100-200$ & $8.96 \times 10^{-3}$ & \\
\hline & 400 & 1.03 & $200-400$ & $4.92 \times 10^{-3}$ & \\
\hline & 800 & 0.86 & $400-800$ & $2.41 \times 10^{-3}$ & \\
\hline \multirow{6}{*}{$\begin{array}{l}\text { Sedimentasyon } \\
\text { Deneyinden } \\
\text { (sedimentasyon } \\
\text { numunesi) }\end{array}$} & 25 & 1.48 & $0-25$ & $4.16 \times 10^{-3}$ & \multirow{6}{*}{0.70} \\
\hline & 50 & 0.52 & $25-50$ & $2.54 \times 10^{-3}$ & \\
\hline & 100 & 1.03 & $50-100$ & $1.49 \times 10^{-3}$ & \\
\hline & 200 & 0.94 & $100-200$ & $0.84 \times 10^{-3}$ & \\
\hline & 400 & 1.38 & $200-400$ & $4.60 \times 10^{-3}$ & \\
\hline & 800 & 1.29 & $400-800$ & $2.31 \times 10^{-3}$ & \\
\hline
\end{tabular}

Model Deney 1'den alınan tüp numune üzerinde yapılan konsolidasyon deneyinde gerilme artışına bağlı olarak c c'nin azaldığı belirlenmiştir. Sedimantasyon numunesinden belirlenen $c_{v}$ değerleri ile artan gerilme arasında çok tutarlı bir değişim görülmemiştir. Yaklaşık olarak zemin numunelerinin su muhtevalarının deney başında \%78-86 ve deney sonunda \%43.547.6 aralığında değişim gösterdiği belirlenmiştir. Model Deney 1'de alınan örselenmemiş numune üzerinde yapılan konsolidasyon deneyinde, yükleme kademeleri arttıkça $\mathrm{m}_{\mathrm{v}}$ değeri azalma göstermiş, sedimantasyon numunesinde ise gerilme seviyesi arttıkça $\mathrm{m}_{\mathrm{v}}$ değerlerinde düzenli olarak azalma görülmemiştir.

Haliç tarama çamuru üzerinde yapılan deneylerden elde edilen konsolidasyon katsayısı $\left(\mathrm{c}_{\mathrm{v}}\right)$ ve hacimsal sıkışma katsayısı $\left(\mathrm{m}_{\mathrm{v}}\right)$ değerleri literatürde tarama malzemeleri ile yapılmış sıkışabilirlik deneylerinden elde edilen konsolidasyon katsayısı $\left(\mathrm{c}_{\mathrm{v}}\right)$ ve hacimsal sıkışma katsayısı $\left(\mathrm{m}_{\mathrm{v}}\right)$ değerleri ile karşılaştırılmıştır. Literatürde taranmış malzemeler üzerinde Boyle vd. [38], Bergado vd. [39], Ganesalingam vd. [40], Develioğlu ve Pulat [41] tarafindan gerçekleştirilmiş konsolidasyon deney sonuçları yer almaktadır. Bu çalışmalara göre, Boyle vd. [38] tarafından arazide tarama malzemeleri ile yapılan deneme alanlarında yapılan ölçümlerden geri hesaplamalardan belirlenen $\mathrm{c}_{\mathrm{v}}$ değerlerinin 1-2 $\mathrm{m}^{2} / \mathrm{y}$ ll olarak kabul edilebileceği belirtilmiştir. Bergado vd. [39] tarafından Ohio tarama kili üzerinde yapılan sıkışabilirlik deneyleri sonuçlarına göre, Ohio tarama kili‘nin ortalama $c_{v}$ değerleri 0.3-0.4 $\left(\mathrm{m}^{2} / \mathrm{y} 1 \mathrm{l}\right)$ arasında değişirken, 28-220 düşey gerilme aralığ 1 için hesaplanan $\mathrm{c}_{\mathrm{v}}$ maksimum 0.55-0.83 ( $\left.\mathrm{m}^{2} / \mathrm{y} 1 \mathrm{l}\right)$ aralığında olduğu belirtilmiştir. Aynı tarama kilinin 20-164 kPa düşey gerilme aralığında, $\mathrm{m}_{\mathrm{v}}$ değerlerinin ise $12 \times 10^{-3}$ ila $1.74 \times 10^{-4}(\mathrm{kPa})^{-1}$ aralığında olduğu belirtilmiştir. Ganesalingam vd. [40] Avustralya, Queensland Brisbane Limanı'nda yapılan tarama çalışmalarında, tarama zemini üzerinde yapılan konsolidasyon deneylerinde $\mathrm{m}_{\mathrm{v}}{ }^{\text {"nin }}$ 
maksimum ve minimum değerlerini $1.95 \times 10^{-2}$ ve $4 \times 10^{-4}(\mathrm{kPa})^{-1}$ olarak belirlemişlerdir. Develioğlu ve Pulat [41] tarafından İzmir körfezinden alınan tarama malzemesi üzerinde yapılan ödometre deneylerinde $98 \mathrm{kPa}$ düşey gerilme değerinde $\mathrm{m}_{\mathrm{v}}$ değeri $6.30 \times 10^{-4}(\mathrm{kPa})^{-1}$ olarak belirlenmiştir. Buna göre, Haliç tarama çamuru üzerinde yapılan deneylerden elde edilen konsolidasyon katsayısı $\left(\mathrm{c}_{\mathrm{v}}\right)$ ve hacimsal sıkışma katsayısı $\left(\mathrm{m}_{\mathrm{v}}\right)$ değerlerinin literatürde tarama çamurları için elde edilen $c_{v}$ ve $m_{v}$ değerleri ile mertebe olarak uyumlu olduğu görülmektedir.

\subsection{Arazi Deneylerinden Sıkışabilirlik Parametrelerinin Belirlenmesi}

Depolama sahasında yapılan Standart Penetrasyon Deneyinden elde edilen $\mathrm{N}_{60}$ darbe sayılarından Eşitlik 2 [42] kullanılarak hacımsal sıkışma katsyısı $\mathrm{m}_{\mathrm{v}}$ değerleri hesaplanmıştır. $\mathrm{Bu}$ eşitlikte $\mathrm{f}_{2}$ değeri yüksek plastisiteli zeminler için $400 \mathrm{kN} / \mathrm{m}^{2}$ olarak alınmıştır. $\mathrm{m}_{\mathrm{v}}$ değerlerinin derinlikle değişimi Şekil 13'de sunulmuştur. Görüldüğü gibi depolama sahasında taranmış çamurun $\mathrm{m}_{\mathrm{v}}$ değerleri $4.17 \times 10^{-4}-2.54 \times 10^{-3}(\mathrm{kPa})^{-1}$ aralığında değişim göstermektedir.

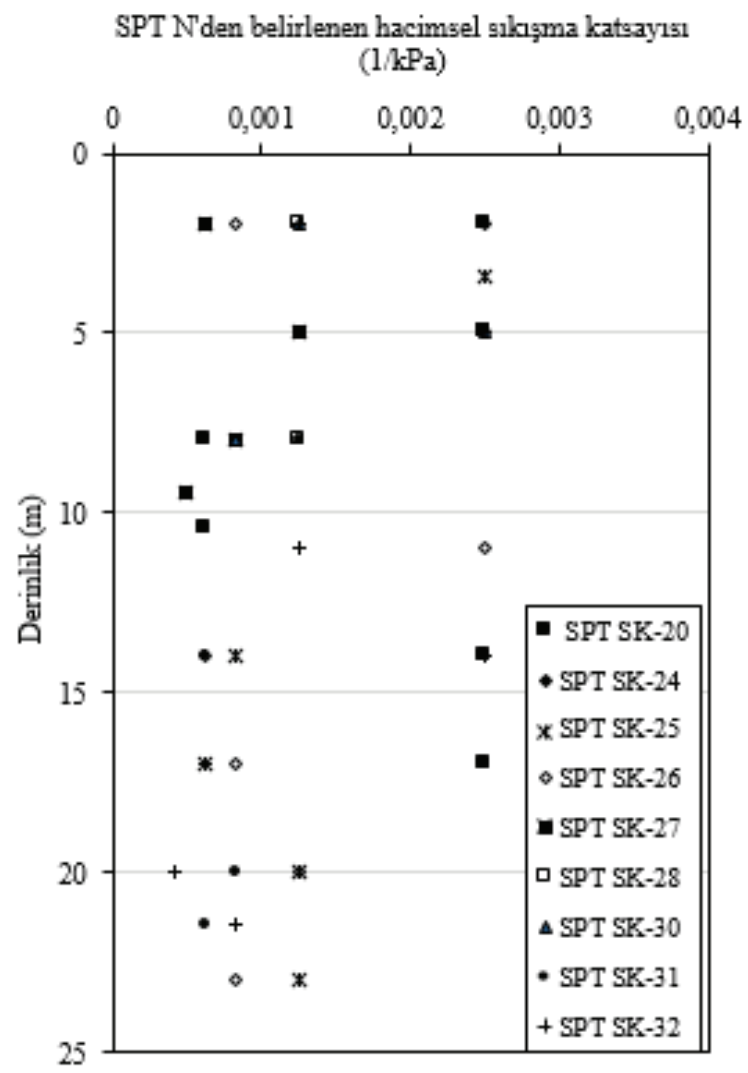

Şekil 13 - SPT N değerlerinden belirlenen $m_{v}$ dĕgerlerinin derinlikle değişsimi 
$m_{v}=\frac{1}{f_{2} * N 60}$

Depolama sahasında yapılan sondajlardan alınan örselenmemiş numuneler üzerinde yapılan standart ödometre deneyi sonuçları Çizelge 5 ve Çizelge 6'da verilmiştir.

Çizelge 5 - 2011 yılında depolama sahasından alınan numuneler üzerinde yapılan ödometre deneylerinden belirlenen sıkışma indisleri

$\begin{array}{ccccc}\begin{array}{c}\text { Sondaj } \\ \text { No }\end{array} & \begin{array}{c}\text { Derinlik } \\ (\mathrm{m})\end{array} & \mathrm{e}_{0} & \begin{array}{c}\mathrm{w}_{\mathrm{o}} \\ (\%)\end{array} & \begin{array}{c}\text { Sikışma İndisi } \\ \mathrm{C}_{\mathrm{c}}\end{array} \\ \text { SK-20 } & 3 & 1.64 & 22 & 0.29 \\ \text { SK-24 } & 3 & 1.20 & 42 & 0.43 \\ \text { SK-24 } & 6 & 1.58 & 53 & 0.69 \\ \text { SK-25 } & 6 & 1.75 & 56 & 0.33 \\ \text { SK-26 } & 3 & 1.58 & 41 & 0.43 \\ \text { SK-26 } & 6 & 1.04 & 44 & 0.32 \\ \text { SK-30 } & 3 & 1.58 & 51 & 0.38 \\ \text { SK-31 } & 3 & 1.71 & 54 & 0.43 \\ \text { SK-31 } & 6 & 1.07 & 49 & 0.37 \\ \text { SK-32 } & 3 & 1.58 & 54 & 0.53 \\ \text { SK-32 } & 6 & 1.72 & 56 & 0.47\end{array}$

Çizelge 6 - 2011 yılında depolama sahasından alınan numuneler üzerinde yapılan ödometre deneylerinden belirlenen hacimsel sıkışma katsayısı

\begin{tabular}{cccccccccc} 
Gerilme & \multicolumn{8}{c}{ Hacimsel sıkışma katsayısı, $\mathrm{m}_{\mathrm{v}}(\mathrm{kPa})^{-1} \times 10^{-3}$} \\
Aralığ1 & SK-20 & SK-24 & SK-24 & SK-25 & SK-26 & SK-26 & SK-30 & SK-31 & SK-32 \\
$(\mathrm{kPa})$ & $3 \mathrm{~m}$ & $3 \mathrm{~m}$ & $6 \mathrm{~m}$ & $6 \mathrm{~m}$ & $3 \mathrm{~m}$ & $6 \mathrm{~m}$ & $3 \mathrm{~m}$ & $3 \mathrm{~m}$ & $6 \mathrm{~m}$ \\
$30-50$ & 1.441 & 1.569 & 1.368 & 1.902 & 2.225 & 2.38 & 2.158 & 2.204 & 2.077 \\
$50-100$ & 1.112 & 1.194 & 1.158 & 1.186 & 1.202 & 1.152 & 1.142 & 1.145 & 1.228 \\
$100-200$ & 0.595 & 0.429 & 0.466 & 0.421 & 0.610 & 0.636 & 0.606 & 0.567 & 0.532 \\
$200-400$ & 0.244 & 0.290 & 0.351 & 0.131 & 0.312 & 0.317 & 0.316 & 0.307 & 0.300 \\
$400-800$ & 0.149 & 0.189 & 0.253 & 0.253 & 0.177 & 0.177 & 0.152 & 0.179 & 0.168
\end{tabular}

Çizelge 4'te laboratuvarda kendi ağırlığı altında konsolide olduktan sonra alınan numunelerden belirlenen $m_{v}$ değerleri sunulmuştur. Çizelge 6' da ise arazide depolamadan 13 yıl sonra zemin yüzünden $3 \mathrm{~m}$ ve $6 \mathrm{~m}$ derinliklerden alınan numunelerde yapılan ödometre deneylerinde belirlenen $\mathrm{m}_{\mathrm{v}}$ değerlerinin değişimi gösterilmiştir. Görüldüğü gibi düşey 
gerilme arttıkça $\mathrm{m}_{\mathrm{v}}$ değerleri azalmıştır (Şekil 14). Laboratuvarda model deneylerden alınan (su muhtevası $\% 77.5$ ) ve araziden alınan numunelerden (su muhtevası aralığ $\% 42-\% 56$ olan) belirlenen hacımsal sıkışma katsayıları arasında yaklaşık olarak 8-17 kat farklılık olduğu belirlenmiştir. Aradan geçen 13 yıl sonrasında arazide meydana gelen su muhtevasındaki değişimle beraber sıkışabilirliğinin de azaldığı belirlenmiştir. Aynı şekilde $C_{c}$ değerleri de laboratuvar örneklerinde 0.70-0.76 aralığında iken, araziden alınan örselenmemiş numunelerde $0.29-0.69$ aralı̆̆ında değişim göstermiştir.

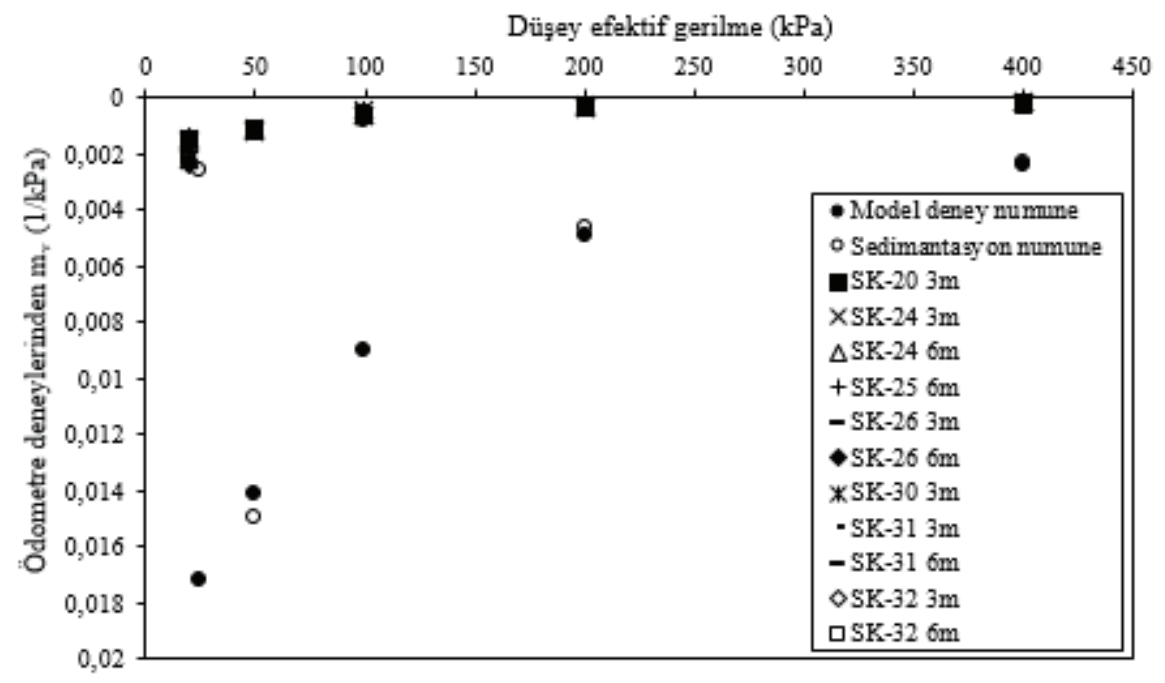

Şekil 14 - Depolama sahası numuneleri üzerinde yapılan ödometre deneylerinden belirlenen hacımsal sıkışma katsayılarının değişimi

\subsection{Drenajsız Kayma Mukavemetinin Değerlendirilmesi}

Model deneylerde sulu çamurun kendi ağırlı̆̆ altına konsolidasyonu tamamlandıktan sonra yapılan veyn deneylerinden belirlenen drenajsız kayma mukavemeti Şekil 15a'da sunulmuştur. Model Deneyl'de dört noktada derinlik boyunca, diğer deneylerde ise üç noktada derinlik boyunca veyn deneyleri yapılmıştır. Deney 1'de ölçülen drenajsız kayma mukavemeti değerlerinin diğer model deneylerden daha büyük olduğu görülmektedir. Bunun nedeni, konsolidasyon sırasında Şekil 2'de gösterilen tankın yan tarafında bulunan vanalardan su çıkışına izin verilmiş olması ve bu deneyde tarama çamurunun kendi ağırlığ altında konsolidasyonu aşamasında daha uzun süre beklenmesidir. Ayrıca, Deney 1'de su muhtevasının diğer deneylerden daha düşük olması da, drenajsız kayma mukavemetinin diğer deneylerde ölçülen değerlerden daha büyük olmasına neden olmuştur (Şekil 15).

Tarama çamurunun kendi ağırlığı altında konsolidasyonu sonucunda ulaştı̆̆ı drenajsız kayma mukavemetini belirlemek için tarama çamurunun depolandığ 1 sahada yapılan SPT-N sonuçlarından da yararlanılmıştır. Bunun için SPT-N darbe sayısı ile drenajsız kayma mukavemeti arasında verilen Eşitlik 3 kullanılmıştı. Bu eşitlikte yer alan $f_{1}$ katsayısı yüksek plastisiteli zeminlerde $4.0 \mathrm{kN} / \mathrm{m}^{2}$ olarak alınmaktadır [42]. Buna göre, Eşitlik 3 kullanılarak 
hesaplanan drenajsız kayma mukavemeti değerleri Şekil 15b'de görüldüğü gibi 4 ile 24 aralığında değişim göstermektedir.

$\mathrm{c}_{\mathrm{u}}=\mathrm{f}_{1} \cdot \mathrm{N}_{60}$

Depolama sahasında 2011 yılında yapılan sondajlardan alınan örselenmemiş numuneler üzerinde konsolidasyonsuz - drenajsız (UU) üç eksenli basınç deneylerinden elde edilen sonuçlar da değerlendirilmiş ve Şekil $15 \mathrm{~b}$ 'de sunulmuştur. Zemin yüzünden $3 \mathrm{~m}$ ile $6 \mathrm{~m}$ derinlikler arasındaki numuneler üzerinde yapılan deneylerden $c_{\mathrm{u}}$ değeri $4-20 \mathrm{kPa}$ aralığında, su muhtevaları ise \%54 ile \%42.5 aralığında değişim göstermiştir. Deneylerde küçük değerlerde kayma mukavemeti açısı $\left(\phi_{\mathrm{u}}\right)$ tespit edilmiştir.
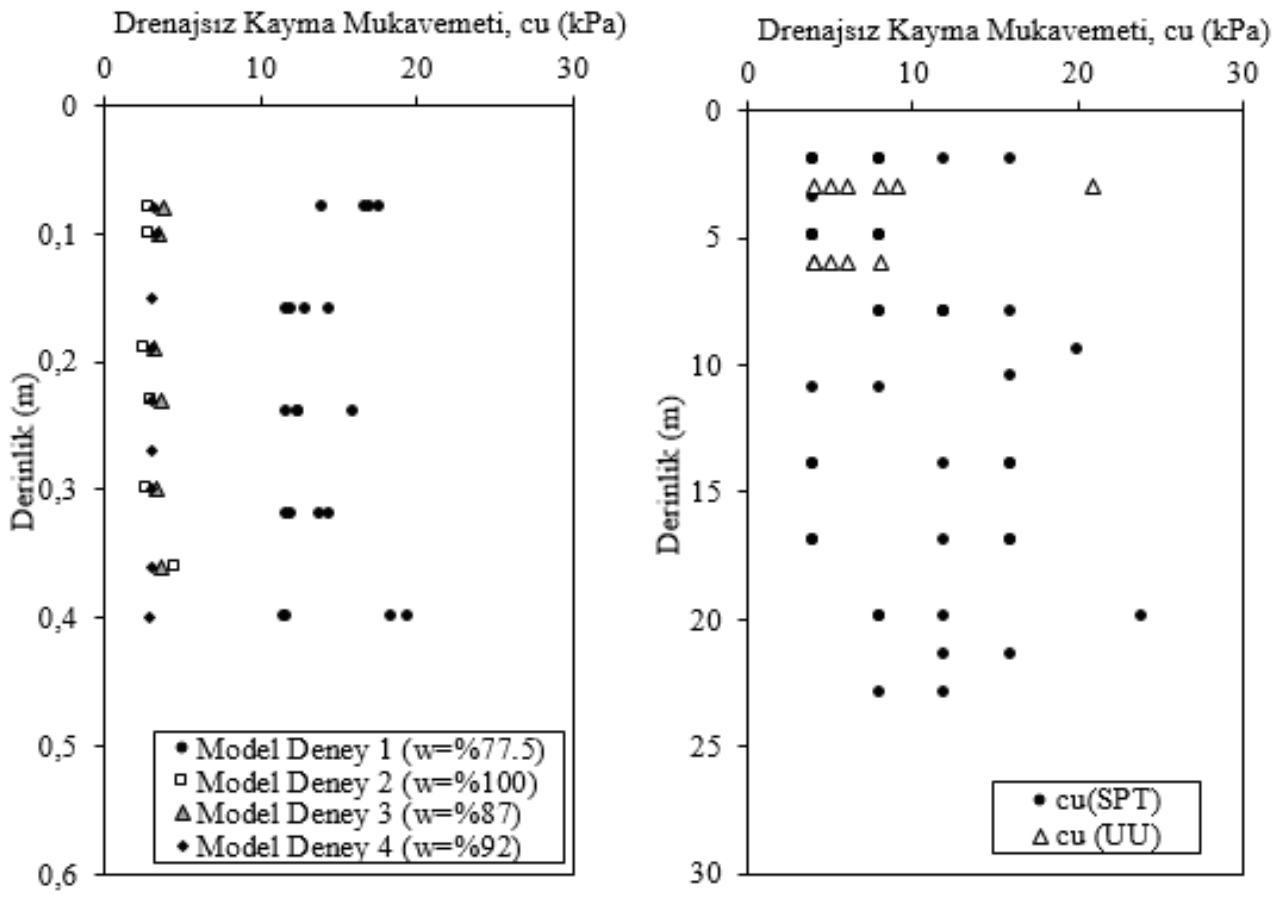

Şekil 15 - (a) Model Deneylerden belirlenen drenajsız kayma mukavemeti (b) Depolama sahasındaki tarama çamurunun drenajsız kayma mukavemeti

\section{4. ÇAMUR DEPOLAMA SAHASININ REHABILITASYONU KAPSAMINDA SAHANIN OTURMA VE TAŞIMA GÜCÜ DAVRANIŞI AÇISINDAN DEĞERLENDİIILMESI}

Haliç'ten taranan ve eski taş ocağında depolanan tarama çamurunun çökelme ve kendi ağırlığı altındaki konsolidasyon sürecinden yaklaşık 13 yıl gibi bir süre geçtikten sonra taranmış çamurun depolandığı sahanın üzerinde bir tema park inşa edilerek yeniden kullanıma kazandırılması mümkün olmuştur. 
Tarama çamurunun depolandığı alanda inşa edilen tema parkın proje tasarım aşamasında, tarama çamurunun taşıma gücü ve sıkışabilirlik davranışı laboratuvardan ve araziden elde edilen veriler ışığında değerlendirilmiştir. Bu kapsamda, depolama sahasında yapılan sondajlardan alınan örselenmemiş numuneler üzerinde yapılan UU üç eksenli basınç (Şekil 16b) ve model tank deneylerinde yapılan veyn deneylerinden elde edilen drenajsiz kayma mukavemeti $\left(\mathrm{c}_{\mathrm{u}}\right)$ değerleri (Şekil 16a) ile model deneylerde yapılan plaka yükleme deneylerinden (Şekil 7) yararlanılarak tarama çamurunun taşıma gücü değeri hesaplanmıştır. Tarama çamurunun depolandığ UU deneylerinden belirlenen $c_{\mathrm{u}}$ değerleri 4-20 kPa aralığında değişmektedir (Şekil 16b). Kendi ağırlığı altında konsolidasyon sonucunda arazideki su muhtevasına en yakın su muhtevası olan \%54 nihai su muhtevasına ulaşan model tank deneyinde (Model 1) $\mathrm{c}_{\mathrm{u}}$ değerleri ortalama $12 \mathrm{kPa}$ olarak ölçülmüştür. Deneysel olarak ölçülen $\mathrm{c}_{\mathrm{u}}$ değerlerine göre hesaplanan taşıma gücü değerleri ile plaka yükleme deneyinden belirlenen taşıma gücü değeri Çizelge 7'de verilmiştir. Elde edilen verilere göre tarama çamurunun taşıma gücü yaklaşık olarak $50 \mathrm{kPa}$ mertebelerindedir.

\section{Çizelge 7 - Depolanan malzemenin taşıma gücü tahmini}

\section{Deney}

Plaka Yükleme deneyi (model deney)

UU Üç eksenli basınç deneyi*

Veyn deneyi*

*Tașıma gücü değeri $\phi u=0$ koșulu için, qu=5.14cu eșitliğinden heaplanmıstır.
Taşıma Gücü $\left(\mathrm{q}_{\mathrm{u}}\right)(\mathrm{kPa})$

50

45

60

Model deneylerde gözlenen oturma davranışı Asoaka [36] yöntemi ile değerlendirilmiş ve dört model deneyden ve sedimentasyon deneyinden kendi ağırlığ 1 altında konsolidasyon sürecinde nihai oturma değerine ulaşıldığı ve sırasıyla konsolidasyon katsayısının $\left(\mathrm{c}_{\mathrm{v}}\right)$ yaklaşık $10.72-0.91 \mathrm{~m}^{2} / \mathrm{y} 1 \mathrm{l}$ ve $8.51 \mathrm{~m}^{2} /$ yıl olduğu saptanmıştır. Bu durumda ortalama $25 \mathrm{~m}$ kalınlığında arazide depolanan Haliç tarama çamurunun, çift yönlü drenaj koşullarında \%90 konsolidasyonunu tamamlaması için gerekli sürenin yaklaşık 12.36 - 25 yıl aralığında olduğu tahmin edilmiştir. Görüldüğü gibi laboratuvar model deneylerinden belirlenen $\mathrm{c}_{\mathrm{v}}$ değerleri ile arazide depolanan çamurun kendi ağırlığı altında konsolidasyon süresi (13 yıl) oldukça yakın tahmin edilmiştir. Bununla birlikte, depolama sahası üzerinde yaklaşı $100 \mathrm{kPa}$ değerinde bir yükleme durumu göz önüne alındığında, tarama çamurunda meydana gelecek oturma miktarı (S) ortalama bir $\mathrm{m}_{\mathrm{v}}=1.2 \times 10^{-3} \mathrm{kPa}^{-1}$ değeri kullanılarak yaklaşık olarak aşağıdaki şekilde hesaplanabilir;

$\mathrm{S}=\mathrm{q} \cdot \mathrm{m}_{\mathrm{v}} \cdot \mathrm{H}=100 \times\left(1.2 \times 10^{-3}\right) \times 25=3 \mathrm{~m}$ mertebesindedir.

Burada, H; tarama çamurunun kalınlığı olup araziden alınan verilere (Şekil 9) göre ortalama $25 \mathrm{~m}$ alınmıştır. Hesaplanan bu oturma değeri oldukça yüksek bir değer olup, depolama sahasında 13 yıl kendi ağırlığı altında bekletilen tarama çamurunun çok yüksek bir oturma potansiyeline sahip olduğunu göstermektedir. 
Sonuç olarak, depolama sahası'nda yaklaşık $25 \mathrm{~m}$ kalınlığındaki tarama çamuru için yukarıda özetlenen taşıma gücü ve sıkışabilirlik parametreleri değerlendirildiğinde, tarama çamurunun çok yüksek sıkışabilirliğe ve düşük taşıma gücüne sahip zemin özellikleri taşıdığı görülmektedir. Bu nedenle, taranmış çamurun depolandığı sahanın üzerinde inşa edilmiş olan tema park kapsamındaki yapı temellerinin sağlam tabaka olan Trakya Formasyonu'na oturtulması ve tarama çamurunun katkı maddeleri ile iyileştirilerek, sıkışabilirlik ve taşıma gücü özelliklerinin arttırılması yoluna gidilmiştir.

\section{SONUÇLAR}

Haliç Tarama Projesi kapsamında yapılan araştırmalar sonucu taranan 5 milyon metreküp dipsel çamur Alibeyköy'de kullanılmayan eski taş ocaklarında depolanmıştır. Haliç'den taranan çamurun sahada depolanmasından yaklaşık 13 yıl sonra, depolama alanı ve çevresini de içine alacak şekilde inşası planlanan yapıların tasarımı için sondaj çalışmaları gerçekleştirilmiştir. Yapılan bu çalışmaların değerlendirilmesi sonucu depolanan tarama çamurunun kendi ağırlığ 1 altında konsolidasyonu sonrasındaki durumu tespit edilmiştir. Yapılan çalışmalar ile İstanbul/Alibeyköy'de yer alan ve atıl halde bulunan bir taş ocağı sahası rekreasyon alanına dönüşmüştür.

Bu makalede, Haliç tarama çamurunun karada depolanması durumunda, kendi ağırlığı ve sürşarj yükleri altındaki sıkışma ve mukavemet davranışı laboratuvarda ve arazide yapılan araştırmaların sonuçlarına göre değerlendirilmiştir.

Laboratuvarda yapılan model deneylerde, zeminin kendi ağırlığı altındaki konsolidasyonunda $\mathrm{c}_{\mathrm{v}}$ 'nin $0.91-10.72 \mathrm{~m}^{2} / \mathrm{y}$ ll aralığında değiştiği ve bu değerlerin de literatürde benzer çalışmalardan elde edilen sonuçlarla uyumlu olduğu görülmüştür. Sürşarj gerilmeleri etkisindeki davranışı incelemek için Model Deney 1' den alınan örselenmemiş tüp numune üzerinde yapılan klasik ödometre deneyinde, gerilme artışına bağlı olarak konsolidasyon katsayısı ve hacimsel sıkışma katsayılarında azalma belirlenmesine rağmen küçük boyutlu deneyden alınan sedimentasyon numunesinde benzer davranış belirlenememiştir.

Model Deneylerde kendi ağırlığı altında konsolidasyon tamamlandıktan sonra yapılan veyn deneyleri ile derinlik boyunca belirlenen drenajsız kayma mukavemeti $\mathrm{c}_{\mathrm{u}}=4-20 \mathrm{kPa}$ arasında değişim göstermiştir. Tarama çamuru karada depolandıktan 13 yıl sonra yapılan sondajlardan, belirlenen drenajsız kayma mukavemeti de (SPT N darbe sayısına bağlı olarak ve UU deneylerinden) benzer şekilde $\mathrm{c}_{\mathrm{u}}=4-20 \mathrm{kPa}$ arasında değişim göstermiştir. Depolama sonrası tarama çamurunun sürşarj yükleri altındaki davranışını incelemek için laboratuvarda model deneylerden alınan örnekler ve araziden alınan örselenmemiş numuneler üzerinde yapılan standart ödometre deneylerinden, hacimsal sıkışma katsayısının sürşarj gerilmesi artışına bağlı olarak azaldığı görülmüştür.

Haliç'ten taranan ve eski taş ocağında depolanan tarama çamurunun depolandığ 1 sahada yapılacak tasarımlar için, laboratuvardan ve araziden elde edilen verilere göre tarama çamurunun taşıma gücü yaklaşık $50 \mathrm{kPa}$ olarak belirlenmiştir. Depolama sahası'nda yaklaşık $25 \mathrm{~m}$ kalınlıkta yer alan tarama çamuru için hesaplanan taşıma gücü ve sıkışabilirlik parametreleri değerlendirildiğinde, tarama çamurunun düşük taşıma gücüne ve yüksek sıkışabilirliğe sahip olduğu tespit edilmiştir. 
$\mathrm{Bu}$ araştırma elde edilen sonuçlardan, karada depolanan su muhtevası yüksek çamurların davranışının laboratuarda deneysel olarak modellenebileceği gösterilmiştir. Taranmış dipsel deniz çökelleri gibi sulu çamurların kendi ağırlığı altında ve sürşarj yükleri altında konsolidasyon, mukavemet davranışı ve taşıma gücü model deneyleri, depolama alanında yapılan sondajlardan elde edilen veriler ile karşılaştırılmış, model deneylerde gözlenen davranış ile arazi deney ve sondajlardan elde edilen verilerin oldukça uyumlu olduğu görülmüştür. Karada depolanan çamurun, kendi ağırlığı altındaki konsolidasyon süresi laboratuvar model deneylerinden belirlenen $c_{v}$ değeri kullanılarak oldukça yakın olarak tahmin edilmiştir. Bu nedenle, bu tür projelerde arazi uygulamalarının planlanması ve uzun süreli davranışının öngörülebilmesi çalışmalarında model deneylerin önemli bir katkı sağladığ 1 düşünülmektedir.

\section{Teşekkür}

Çalışma ekibi, İstanbul Büyükşehir Belediyesi'nin Haliç Rehabilitasyon Projesi kapsamında yürüttüğü çalışmalar ile bilgi ve deneyimlerinden her zaman yararlanma olanağı bulduğumuz Sayın Prof. Dr. Kutay Özaydın'a ve deneysel çalışmalara verdiği destekten ötürü Prof. Dr. Mehmet Berilgen'e ve Doç. Dr. Saadet Berilgen'e teşekkür eder.

\section{Semboller}

$\begin{array}{ll}\mathrm{c}_{\mathrm{u}} & \text { Drenajsız kayma mukavemeti } \\ \mathrm{c}_{\mathrm{v}} & \text { Konsolidasyon katsayısı } \\ \mathrm{C}_{\mathrm{c}} & \text { Sıkışma İndisi } \\ \mathrm{CL} & \text { Düşük plastisiteli kil } \\ \mathrm{CH} & \text { Yüksek plastisiteli kil } \\ \mathrm{e} & \text { Boşluk oranı } \\ \mathrm{e}_{0} & \text { Başlangıç boşluk oranı } \\ \mathrm{f}_{1} & \text { Plastisite indisine bağlı katsayı } \\ \mathrm{f}_{2} & \text { Plastisite indisine bağlı katsayı } \\ \mathrm{H} & \text { Sıkışan tabakanın kalınlığı } \\ \mathrm{K} & \text { Permeabilite katsayısı } \\ \mathrm{MH} & \text { Yüksek plastisiteli silt } \\ \mathrm{m}_{\mathrm{v}} & \text { Hacimsel sıkışma katsayısı } \\ \mathrm{N} & \text { Standart Penetrasyon Sayısı } \\ \mathrm{UU} & \text { Konsolidasyonsuz drenajsı üç eksenli basınç deneyi } \\ \Delta \mathrm{t} & \text { Zaman aralığı }\end{array}$




$\begin{array}{ll}\text { SPT } & \text { Standart Penetrasyon Deneyi } \\ \mathrm{S}_{1}, \mathrm{~S}_{2}, \ldots, \mathrm{S}_{\mathrm{n}} & \text { Oturma miktarları } \\ \mathrm{S}_{\mathrm{f}} & \text { Nihai oturma miktarları } \\ \beta & \text { Doğrunun eğimi } \\ \mathrm{w} & \text { Su muhtevası } \\ \mathrm{W}_{\mathrm{L}} & \text { Likit limit } \\ \mathrm{W}_{0} & \text { Başlangıç su muhtevası } \\ \mathrm{W}_{\mathrm{P}} & \text { Plastik limit } \\ \sigma_{\mathrm{v}}^{\prime} & \text { Efektif düşey gerilme } \\ \emptyset_{\mathrm{u}} & \text { Drenajsız içsel sürtünme açısı } \\ \mathrm{q}_{\mathrm{u}} & \text { Serbest basıç mukavemeti }\end{array}$

\section{Kaynaklar}

[1] Pane, V., Schiffman, R.L., A note on sedimentation and consolidation. Geotechnique, $35,1,69-77,1985$.

[2] Abu-Hejleh, A.N., Znidarci, D., Barnes, B.L., Consolidation characteristics of phosphatic clays. American Society of Civil Engineers Journal of Geotechnical Engineering, 122, 295-301, 1996.

[3] Ortenblad, A., Mathematical theory of the process of consolidation of mud deposits. Journal of Mathematical Physics, 9, 73-149, 1930.

[4] Gibson, R. E., The progress of consolidation in clay layer increasing in thickness with time, Geotechnique, 8, 171-182, 1958.

[5] Imai, G., Setting behavior of clay suspension. Soils and Foundations. 20, 61 - 77, 1980.

[6] Imai, G., Experimental studies on sedimentation mechanism and sediment formation of clay minerals. Soils and Foundations, 21, 7-20, 1981.

[7] Gibson, R. E., Schiffman, R. L., Cargill, K. W., The theory of one-dimensional consolidation of saturated clays. II. Finite nonlinear consolidation of thick homogeneous layers. Canadian Geotechnical Journal, 18, 280-293, 1981.

[8] Been, K., Sills, G.C., Self-weight consolidation of soft soils: An experimental and theoretical study. Geotechnique 31, 519-535, 1981.

[9] Koppula, S.D., Morgenstern, N.R., On the consolidation of sedimenting clays. Canadian Geotechnical Journal, 19(3), 1982.

[10] Booker, J. R., Rowe, R. K., 1-D consolidation of periodically layered soil, Journal of Engineering Mechanics, 109, 1319-1333, 1983. 
[11] Bitzer, K., Modeling consolidation and fluid flow in sedimentary basins, Computers and Geosciences, 22, 467-478, 1996.

[12] Fox, P. J., Berles, J. D., CS2: a piecewise-linear model for large strain consolidation, International Journal for Numerical and Analytical Methods in Geomechanics, 21, 453-475, 1997.

[13] Battaglio, M., Bellomo, N., Bonzani, I., Lancellotta, R., Nonlinear consolidation models of clay with change type. International Journal of Non-Linear Mechanics, 38, 493-500, 2003.

[14] Xie, X., Zhang, J., Zeng, G., Similarity solution of self-weight consolidation problem for saturated soil. Applied Mathematics and Mechanics, 26, 1165-1171, 2005.

[15] Hawlader, B. C., Muhunthan, B., Imai, G., State-dependent constitutive model and numerical solution of self-weight consolidation, Geotechnique, 58, 133-141, 2008.

[16] Kondo F, Torrance JK., Effects of Grain-Size distribution, Iron Oxide, and Organic matter in sedimentation and self-weight consolidation on thoroughly disturbed soft marine clay. Transactions of the Japan Society of Irigation Drainage and Reclamation Engineering, 260, 57-67, 2009.

[17] Xu, G.Z., Gao, Y.F., Hong, Z.S., Ding, J.W., Settlement behavior of four dredged slurries in China. Marine Georesources and Geotechnology, 30, 143-156, 2012.

[18] He, J., J. Chu, S. K. Tan, T. T. Vu., K. P. Lam, Sedimentation behavior of flocculanttreated soil slurry. Marine Georesources and Geotechnology, 35,593-602, 2016.

[19] Zeng, L.-L., Z.-S. Hong, W.-B. Tian, and J.-W. Shi, Settling behavior of clay suspensions produced by dredging activities in China. Marine Georesources and Geotechnology, 36, 30-37, 2016.

[20] Zhang, N., W. Zhu, H.-T. He, Y.-Y. Lv, and S.-W. Wang, Experimental study on settling velocity of soil particles in dredged slurry. Marine Georesources and Geotechnology, 35, 747-757, 2016.

[21] Monte, J.L., Krizek, R.J., One-dimensional mathematical model for large-strain consolidation. Geotechnique, 26, 495-510, 1976.

[22] Liu, J.C., Znidarcic, D., Modeling one-dimensional compression characteristic of soils. American Society of Civil Engineers Journal of Geotechnical Engineering, 117, 161$169,1991$.

[23] Gibson, R.E., England, G.L., Hussey, M.J.L., The theory of one dimensional consolidation of saturated clays, I: Finite nonlinear consolidation of thin homogeneous layers. Geotechnique, 17, 261-273, 1967.

[24] Gibson, R. E., Schiffman, R. L., Cargill, K. W., The theory of one-dimensional consolidation of saturated clays. II. Finite nonlinear consolidation of thick homogeneous layers. Canadian Geotechnical Journal, 18, 280-293, 1981.

[25] Toorman, E. A., Sedimentation and self-weight consolidation:General unifying theory. Geotechnique, 46 (1):103-13, 1996. 
[26] Özaydın, K., Yıldırım, S., Yıldırım, M., Kılıç, H., Akgüner, C., Nihai (Beşinci) Geoteknik Rapor, T.C. İstanbul Büyükşehir Belediye Başkanlığı Haliç Islah ProjesiFizilipite Raporu için Taban Çamurunun Geoteknik ve Kirlilik Özelliklerinin Belirlenmesi ve Çamurun Taranması ve Uzaklaştırılması Projesi, Kasım 1995.

[27] Berilgen, S.A., Biçer, P., Berilgen M., and Ozaydın, K., Assessment of consolidation behavior of golden horn marine dredged material. Marine Georesources and Geotechnology, 24, 1-16, 2006.

[28] Berilgen, M. M., Ozaydin, K., Edil, T., A case study:dredging and disposal of Golden Horn. In T. B. Edil and P. J. Fox (eds.), Geotechnics of High Water Content Materials, ASTM STP 1374. West Conshohocken, Pennsylvania, USA: American Society for Testing and Materials. (1999).

[29] Metropol Mühendislik, İstanbul ili, Eyüp ilçesi, Yeşilpınar mahallesi/ Alibeyköy Sınırlarında planlanan İstanbul Tema Parkı ve Eğlence Merkezi Zemin Etüd Raporu, Samsun, 2011.

[30] ASTM D 2487. Standard Practice for Classification of Soils for Engineering Purposes Unified SoilClassification System). American Society for Testing and Materials Philadelphia.

[31] ASTM D4318-10, Standard Test Methods for Liquid Limit, Plastic Limit, and Plasticity Index of Soils, ASTM International.

[32] ASTM-D 2974-14, Standard Test Methods for Moisture, Ash and Organic Matter of Peat and Other Organic Soils, ASTM International, West Conshohocken, PA.

[33] İpekoğlu, P., Atık Çamur Sahalarının Rehabilitasyonu. Doktora Tezi, YTÜ İnşaat Mühendisliği Bölümü, Geoteknik Anabilim Dalı, 2004.

[34] Fox, P. J., Berles, J. D., CS2: a piecewise-linear model for large strain consolidation, International Journal for Numerical and Analytical Methods in Geomechanics, 21, 453-475, 1997.

[35] İnce, Ç. G., Sulu Çamurların Sedimentasyonu ve Konsolidasyonu. Yüksek Lisans Tezi, YTÜ İnşaat Mühendisliği Bölümü, Geoteknik Anabilim Dalı, 1998.

[36] Asaoka, A., Observational Procedure of Settlement Prediction of Settlemen. Soils and Foundation., 18, 4, 87-101, 1978.

[37] Casagrande, A., The Determination of the Pre-Consolidation Load and Its Practical Significance, Discussion D-34, Proc. of First INT: Conf. on Soil Mech. And Found. Eng., Cmbridge, III, 60-64, 1936.

[38] Boyle, P., Berthier, D., Holding, G., Ameratunga, J., De Bok, C., Successful Application of vacuum consolidation at Port of Brisbane. Ground Improvement Technologies and case histories, GeoSS, Singapore, 747-753, 2009.

[39] Bergado, D.T., Singh, N., Sim, S.H., Panichyatum, B., Sampaco, C.L., Balasubramaniam, A.S., Improvement of soft Bangkok clay using vertical geotextile band drains compared with granular piles. Geotextiles and Geomenbranes, 9: 203-201, 1990. 
[40] Ganesalingam, D., Arulrajah, A., Ameratunga, J., Boyle, P. J., Sivakugan, N., Geotechnical properties of reconstituted dredged mud. Proceedings from the Pan-AM CGS Geotechnical Conference (pp. 1-7). Toronto, Canada. (2011).

[41] Develioğlu İ., Pulat FH., Compressibility behaviour of natural and stabilized dredged soils in different organic matter content. Construction and Building Materials, 228, 1$11,2019$.

[42] Stroud, M.A., The standard penetration test in insensitive clays and soft rock, Proceedings of European Symposium on Penetration Resistance. National Swedish Institute for Building Research, Stockholm, Sweden, 2.2, 367-375, 1974. 
